Capulli, MacQueen, et al. Fibrous Scaffolds for Building Hearts I Last Edited: 11/12/2015

\title{
Fibrous Scaffolds for Building Hearts and Heart Parts
}

A. K. Capulli ${ }^{1}$, L. A. MacQueen ${ }^{1}$, Sean P. Sheehy, and K. K. Parker*

*Disease Biophysics Group, Wyss Institute for Biologically Inspired Engineering, John A. Paulson School of Engineering and Applied Sciences, Harvard University, Cambridge, MA, USA

${ }^{1}$ These authors contributed equally to this work.

\section{Corresponding author:}

Kevin Kit Parker, Ph.D.

Disease Biophysics Group

Wyss Institute for Biologically Inspired Engineering

John A. Paulson School of Engineering and Applied Sciences

Harvard University

29 Oxford St, Pierce Hall 321

Cambridge MA 02138

E-mail: kkparker@ seas.harvard.edu 
Abstract: Extracellular matrix (ECM) structure and biochemistry provide cell-instructive cues that promote and regulate tissue growth, function, and repair. From a structural perspective, the ECM is a scaffold that guides the self-assembly of cells into distinct functional tissues. The ECM promotes the interaction between individual cells and between different cell types, and increases the strength and resilience of the tissue in mechanically dynamic environments. From a biochemical perspective, factors regulating cell-ECM adhesion have been described and diverse aspects of cell-ECM interactions in health and disease continue to be clarified. Natural ECMs therefore provide excellent design rules for tissue engineering scaffolds. The design of regenerative three-dimensional (3D) engineered scaffolds is informed by the target ECM structure, chemistry, and mechanics, to encourage cell infiltration and tissue genesis. This can be achieved using nanofibrous scaffolds composed of polymers that simultaneously recapitulate 3D ECM architecture, high-fidelity nanoscale topography, and bio-activity. Their high porosity, structural anisotropy, and bio-activity present unique advantages for engineering 3D anisotropic tissues. Here, we use the heart as a case study and examine the potential of ECM-inspired nanofibrous scaffolds for cardiac tissue engineering. We asked: Do we know enough to build a heart? To answer this question, we tabulated structural and functional properties of myocardial and valvular tissues for use as design criteria, reviewed nanofiber manufacturing platforms and assessed their capabilities to produce scaffolds that meet our design criteria. Our knowledge of the anatomy and physiology of the heart, as well as our ability to create synthetic ECM scaffolds have advanced to the point that valve replacement with nanofibrous scaffolds may be achieved in the short term, while myocardial repair requires further study in vitro and in vivo.

Keywords: Nanofiber, scaffold, electrospinning, force spinning, rotary jet spinning, cardiac, myocardium, valve, tissue engineering, regenerative medicine 
Capulli, MacQueen, et al. Fibrous Scaffolds for Building Hearts $\quad$ Last Edited: 11/12/2015

Contents

1. Introduction

2. Design Criteria for Engineered Cardiac Tissues

2.1 Multiscale structure of striated heart muscle

2.2 Cardiac pacing

2.3 Multiscale functional properties of striated heart muscle: conduction and contraction

2.4 Ventricle Elastance and Strain

2.5 Cardiac Valve Structure

3. Fibrous Scaffold Production Techniques

3.1 Decellularized Extracellular Matrix Fibrous Scaffolds

3.2 Synthetically Produced Fibrous Scaffolds

4. Cardiac Tissue Repair Using Fibrous Scaffolds

4.1 Heart Structure Following Injury or Disease

4.2 Fibrous Scaffolds for Myocardial Tissue Regeneration

4.3 Fibrous Scaffolds for Valve Replacement

5. Design Challenges and Future Directions

6. Conclusion

7. References 


\section{Introduction}

In their 2002 Viewpoint article, Hench and Polak [1] described a transition to "ThirdGeneration Biomedical Materials" that stimulate specific cellular responses to promote endogenous tissue regeneration and help the body to heal itself. To accomplish this goal, implanted scaffolds should first minimize toxic response in the host and subsequently recapitulate properties of the native tissue's extracellular matrix (ECM) to promote cell assembly into functional tissues. Mechanotransduction through the cell-ECM interface plays a fundamental role in regulating tissue homeostasis, growth, and regeneration [2-7]. In muscular organs, ECM morphology and elasticity regulate cell shape and coordinate myofibril assembly, thereby influencing tissue architecture and contractile strength [8-11]. Specifically in the heart, a fibrillar ECM network provides guidance cues that direct the spatial and temporal synchrony of cardiac development. Thus, recapitulation of this ECM network using fibrous materials may be a crucial design consideration of engineered cardiac tissues. We therefore asked whether fiberbased scaffolds can be used to guide the assembly of functional cardiac tissues.

The use of fibrous cell culture substrates to study tissue regeneration can be traced back at least a century to the work of Ross Granville Harrison who, in 1914 [12], cultured embryonic frog and chick cells on spider silk, noting that "the solid support influence[d] the form and arrangement assumed by the moving cells" and cells were "arranged with reference to the web fibers, and they [were] usually drawn out into long processes". Contact guided cell growth was subsequently studied on diverse substrates (e.g., glass fibers [13], oriented collagen [14] and micropatterned features [15]) but predictable tissue assembly required discovery and classification of tissue-specific structures, cell types, cell adhesion proteins [16-19], and their interactions with the extra-cellular microenvironment $[4,20,21]$. Extensive study of these 
components and properties of cell-ECM interaction provide a mechanistic understanding of tissue self-assembly that can be incorporated into the design specifications of engineered tissues to guide the development of more physiologically-relevant cellular scaffolds [22-24]. Scaffolds composed of fibrous materials are increasingly used for regenerative medicine because fiber manufacturing platforms now exist capable of producing fibers with a wide range of structural and biochemical properties [25-29]. Fiber scaffolds fabricated using these techniques can mimic the native ECM and be woven or otherwise assembled into organ-scale structures with adequate porosity and structural stability to support cell infiltration and assembly [30]. Moreover, the incorporation of bioactive molecules into synthetic fibrous scaffolds, such as native ECM components and growth factors, may enhance the development of engineered tissues into more accurate tissue analogs and promote healthy integration into diseased or injured tissues [31].

In this review, we focus on the use of fibrous scaffolds for cardiac tissue repair because the heart is one of the least regenerative organs in the body [32] and natural healing processes can result in deleterious remodeling following insult or disease $[33,34]$. We narrow our focus to the myocardium and aortic valve to illustrate the diversity of the heart's sub-structures and the unique requirements for distinct repair strategies. We begin by summarizing properties of the myocardium and heart valves that serve as design criteria for scaffolds. These include multiscale structural and functional properties of the ECM, cells, tissues, and organs that we tabulate and rank according to their current utility in engineering design. We then describe scaffold manufacturing platforms and assess their capabilities to produce scaffolds that meet our design criteria. The effectiveness of nanofibrous scaffolds to promote cardiac cell assembly into functional myocardial tissues is examined by highlighting in vitro and in vivo use of bioactive myocardial patches. Exploratory experiments using myocardial patches provide a test bed for 
Capulli, MacQueen, et al. Fibrous Scaffolds for Building Hearts $\quad$ Last Edited: 11/12/2015

biotic-abiotic interface optimization aimed at restoring tissue-level function. This is important because although heart function can be restored by abiotic prosthetics [35], regenerative strategies that address biological aspects of heart function may improve host integration for more permanent and adaptive repair while eliminating the need for external power sources that currently hamper abiotic artificial hearts and increase the patient's risk of infection. Crucially, cardiac tissue engineering provides increasingly accurate in vitro models of cardiac health and disease for drug discovery [36, 37], cardiac stem cell biology [38-41], and cell-ECM interactions $[33,42,43]$.

\section{Design Criteria for Engineered Cardiac Tissues}

The heart is a muscular pump tasked with continuously providing efficient blood transport throughout the body. This is achieved through hierarchical control of structure and function integrated over multiple spatial scales $[2,6]$. A key challenge in the field of tissue engineering is defining the standards by which successful replication of native tissue function is achieved, particularly in light of increasing demand for patient-relevant tissue models created using human stem cells. What metrics should be used to determine the success of an engineered tissue fabricated using a fibrous scaffold? Physical material properties, two dimensional planar alignment and three dimensional architecture are important aspects of native tissues that must be recreated in engineered scaffolds to guide cellular self-assembly. Additionally, biochemical properties, degradation kinetics, and bioactive components must be optimized to recapitulate or trigger specific in vivo responses and tissue development in engineered tissues meant for implantation. 
In order to fabricate biomimetic tissues that recapitulate the function of the heart, it is first necessary to quantitatively define the relevant structural and performance attributes that define normal physiological function. Although the standard comparison for the developed functionality of an engineered tissue is the native tissue it is designed to repair or replace, should native tissue chemical and mechanical properties also serve as design criteria for fiber scaffolds? Alternatively, should some immature or basic model of the tissue structure and composition be the standard for a fibrous scaffold: a structure and composition that will best initiate scaffold remodeling and tissue formation once implanted? Measurements of physical features and functional outputs, such as those listed in Table 1, can be used to define target values that serve as quality control metrics for assessing the degree to which engineered tissues faithfully mimic their native counterpart (Fig. 1A). Comprehensive, quantitative comparison of engineered tissues versus healthy, mature tissues using machine learning approaches $[44,45]$ and statistical metrics, such as strictly standardized mean difference, could provide robust, standardized quality assurance rubrics for determining the fitness of engineered tissues for regenerative therapy applications [46]. Traditional tissue engineering approaches involve scaffold to tissue fabrication: scaffold production, in vitro cell seeding, in vitro cell-scaffold conditioning to form tissue, and finally implantation. At each phase, metrics are defined to determine success. For example, mechanical/chemical properties of the raw scaffold, efficiency of seeding, degree of remodeling by the cells during conditioning in vitro, and the eventual functionality of the implanted construct. Most importantly, these metrics help to answer the question: Can we build a heart? by allowing one to determine which aspects of tissue structure and function are well defined, and which require further investigation (Fig. 1B). Below, we describe key structural and 
functional properties of the myocardium and cardiac valves that serve as design criteria for engineered fibrous scaffolds capable of restoring normal function after injury or disease.

\subsection{Multiscale structure of striated heart muscle}

Anisotropic tissue architecture is a hallmark of heart muscle which may be recapitulated using nanofibrous scaffolds. It has been shown that the heart can be unraveled (Fig. 2A) [47] to reveal a helical-laminar assembly of hierarchically organized fibrillar structures: Epiphyseal fibers surround the myocardium, perimysial fibers surround groups of cardiomyocytes, and endomysial fibers wrap individual cardiomyocytes [48]. Individual myofibers contain chains of contractile cardiomyocytes that are physically connected by intercalated discs that contain gap junctions which provide electrical continuity and are surrounded by the perimysial ECM (Fig. 2B). Perimysial fibers are mostly parallel with the long axis of the muscle and contribute to the directional contraction of cell bundles [49]. Helically overlapping myocardial fibers are arranged into distinct laminas four to six myocytes thick and separated from adjacent laminas by an extracellular collagen network [50]. The complete arrangement of bundled myofibers around the ventricles forms a helicoid that economizes fiber length and optimizes ejection fraction during ventricular contraction (Fig. 2C) [51].

The complex geometry of the heart arises from precisely choreographed cellular interactions with soluble factors, neighboring cells, and the ECM that guide cellular fate decisions at each stage of development [52-54]. Boundary conditions presented by the ECM potentiate precise and predictable parallel alignment and bundling of myofibrils as they organize within and across cell boundaries during cardiomyocyte development [55-57]. Physical interactions between cardiomyocytes and the ECM mediate transmission of a variety of signaling 
cues that act through a mechanical linkage with the cardiomyocyte cytoskeleton (CSK) that may influence the activation of gene expression programs that direct changes in phenotypic state [2, 11, 58-62]. In the heart, physical attachment of the cardiomyocyte CSK to the surrounding ECM is mediated by costameres, vinculin-containing rib-like bands localized to the z-discs of sarcomeres (Fig. 2D), that encircle the cardiomyocyte perpendicular to its long axis. They serve as sites for cell attachment, bidirectional mechanotransduction between the cell and ECM [63], and mechanical load-dependent modulation of cardiomyocyte development and pathophysiology [64-66]. Regionalized differences in structural and mechanical cues imparted on cardiomyocytes over the course of heart development activate gene regulatory networks that drive cells toward the cell fate attractor states necessary for chamber specification $[11,52,62,67]$. Alterations in the mechanical load on the heart during physiological and pathological hypertrophy have been shown to activate distinct gene expression programs to provide context-specific cellular responses aimed at maintaining heart function in response to the dynamic physical microenvironmental cues elicited in these conditions [68]. In the healthy myocyte, integrins are commonly localized within costameres, anchoring the sarcomeric z-discs in the outer most regions of the myofibrillar array [2]. In long-term monolayer culture, cardiomyocytes remodel their adhesive structures and reorganize costameres into planar focal adhesions found in nonmuscle cells [69] suggesting that cardiomyocyte contractility would be optimal in a 3D ECM environment that allows the adoption of the rod-like architecture that typifies the adult myocardium. Further, the native myocardial ECM supports dynamic mechanical loading that places specific requirements on surrogate materials used in myocardial tissue engineering to provide an appropriate set of physical cues that activate the gene regulatory networks that give rise to desirable structural and functional properties. 
The relative proportions of ECM proteins such as collagens, fibronectin, and laminin, change during development and maturation of myocardial tissues, reflecting developmental stage-dependent differences in regenerative capacities arising from this shift in ECM composition (Table 2). It has been shown that cardiomyocytes are sensitive to the increase in microenvironmental elasticity that results from increased collagen I expression during development, demonstrating an increase in myofibril protein expression and sarcomere alignment with increased tissue elasticity [70]. The adult myocardium is one of the least regenerative tissues in the body and cardiomyocyte deficiency underlies most causes of heart failure [32]. Cardiomyocyte renewal rates in the postnatal heart are not definitively known [71]: Bergmann et al. [72] estimated that $\sim 50 \%$ of cardiomyocytes are renewed over a normal human lifespan but higher rates were reported in young adults by Mollova et al. [73]. There is also evidence that in both neonatal and adult mammals, proliferation of pre-existing cardiomyocytes contributes to myocyte turnover [74] and that myocyte turnover can be enhanced by the ECM [43]. Further elucidation of the role that the ECM plays in regulating myocyte proliferation may provide a possible strategy to engineer scaffolds that recapitulate the endogenous myocardial regenerative capacity observed during early stages of heart development. This forms the basis of a vertically-integrated developmental build that gives rise to synchronous formation of the heart chambers and the supporting components that allow coordinated electrical and contractile function.

\subsection{Cardiac pacing}

Cardiac contractions are controlled by the sinoatrial (SA) node and Purkinje fibers that form a specialized excitatory and conduction system [75]. The SA node is the pacemaker of the 
heart, responsible for initiation of the heartbeat and the branching Purkinje fibers ensure that impulses are rapidly conducted throughout the heart to synchronize contraction and optimize ejection fraction. Life-threatening arrhythmias resulting from dysfunctional pacing have been revolutionized by electronic pacemakers but their reliance on batteries and electronic control systems highlight potential advantages of biological or bio-electronic tandem approaches to cardiac pacing [76, 77], including genetic engineering [78] and cell implantation [79]. The recent advent of cardiac optogenetics, where transgenic expression of light-gated ion channels permits optical control of cardiac pacing [80, 81] and termination of reentrant electrical activation [82] (e.g., spiral waves), suggests that gene and cell delivery methods can be used to impart light sensitivity on cardiac tissues for - low-energy pacing of target cells [83]. In addition to the promise of optogenetics for developing improved tissue engineered pacemakers, it is also necessary to faithfully recapitulate the anisotropic electromechanical syncytium of healthy myocardial tissue to ensure proper electrical propagation and contractile synchrony.

\subsection{Multiscale functional properties of striated heart muscle: conduction and contraction}

In order to maintain efficient heart function, the myocytes comprising the myocardium must maintain parallel alignment of sarcomeres and form electro-mechanical linkages between individual cardiomyocytes comprising myocardial tissues to ensure coordinated activity across multiple spatial scales, up to the organ level (Fig. 3A). At the nanoscale, CSK/ECM coupling ensures that cardiomyocyte CSK and motor units align in the direction of the ECM for coordinated propagation of excitation wavefronts through gap junctions in the cardiac musculature. Interruption of the ordered wavefront propagation can be arrhythmogenic and is associated with various cardiomyopathies [2]. Conduction velocity (CV) is consistently greatest 
in the fiber direction such that longitudinal $\mathrm{CV}_{\mathrm{L}}$ exceeds transverse $\mathrm{CV}_{\mathrm{T}}$ by a factor of $\sim 2-10$, depending on measurement region and pacing rate (Table 3) [84, 85]. 3D mapping of activation projected onto tissue structure reveals that electrical activity spreads in three distinct directions from an intramural LV point stimulus, corresponding with local microstructural axes [86]. Active electric properties were determined to be anisotropic transverse to the myofiber direction, and principal local CVs in the fiber direction and transverse to it were $67 \pm 1.9,30 \pm 1$, and $17 \pm 0.4$ $\mathrm{cm} / \mathrm{sec}$ (anisotropy ratios: 4:1 \& 8:1). The laminar architecture of ventricular myocardium thus gives rise to orthotropic electric properties with slow propagation normal to laminae [86, 87].

Contractile force generated by the heart increases with increasing myocardial strain during diastole. This fundamental property whereby the heart synchronizes cardiac output with venous return is known as the "Frank-Starling Law" and was appreciated by $19^{\text {th }}$ century physiologists [88]. We now know that calcium-dependent activation of sarcomeric proteins underlies this length-tension relationship [89-95] and tension generated by individual cardiomyocytes depends on cell and sarcomere length, SL (Fig 3B, C, Table 4) [96-99]. As summarized by Shiels \& White [96] in their commentary on the Frank-Starling mechanism in vertebrate cardiomyocytes, end systolic SL $\sim 1.9-2.0 \cdot \mu \mathrm{m}$ and end diastolic SL $\sim 2.2-2.4 \cdot \mu \mathrm{m}$. SLdependent cardiomyocyte contractile force scales to volume-dependent ventricle contractile force and stroke work due to coordinated activity of the myocardial syncytium.

Conduction velocities are generally lower in engineered tissues than in whole organs. Whereas longitudinal and transverse conduction velocities $\left(\mathrm{CV}_{\mathrm{L}}\right.$ and $\mathrm{CV}_{\mathrm{T}}$, respectively) are on the order of $\mathrm{CV}_{\mathrm{L}} \sim 20 \mathrm{~cm} / \mathrm{s}$ and $\mathrm{CV}_{\mathrm{T}} \sim 10 \mathrm{~cm} / \mathrm{s}$ for engineered tissues, they are $\mathrm{CV}_{\mathrm{L}} \sim 70 \mathrm{~cm} / \mathrm{s}$ and $\mathrm{CV}_{\mathrm{T}} \sim 25 \mathrm{~cm} / \mathrm{s}$ for whole human left ventricles (Table 3). Conduction velocity depends on gap junctional conductance (in silico: [100]) that is partly determined by the activity of gap 
junction channel proteins, the assembly and function of which may be limited in vitro using previously dissociated cells [101]. Similarly, contractile stresses generated by whole organs are larger than those generated by engineered tissues. Whereas human LV contractile stresses are on the order of $100 \mathrm{kPa}$, human ventricular muscle strips generated $\sim 40 \mathrm{kPa}$ and hESC-CM $\sim 12 \mathrm{kPa}$ (Table 4). This discrepancy is expected when immature stem cell-derived cardiomyocytes are used to build tissues or when cells that are isolated from patients loose function in vitro. As with the case of conduction velocities, this discrepancy may arise, at least in part, from non-ideal cell connectivity. We expect improved stem cell maturation protocols and in vitro culture methods to reduce the gap between engineered and natural tissue contractile stress generation capacity. Fibrous scaffolds can play a significant role here, as they provide 3D in vitro cell culture substrates that can guide cardiomyocyte assembly and promote functional maturation.

\subsection{Ventricle Elastance and Strain}

Myocardial tissue is mechanically dynamic with time-dependent elastic properties, some of which are listed in Table 5. Ventricular end systolic/diastolic pressure/volume relations (ESPVR/EDPVR) are used to estimate LV elastance in systole or diastole [102]. Shear stiffness during LV contraction closely matches chamber pressure during diastole, and systole (Fig. 3D), demonstrating the importance of designing fibrous scaffolds capable of withstanding dynamic changes in the mechanical environment [103]. In contrast to the nonlinear EDPVR, the ESPVR is approximately linear over a wide range of conditions and its slope, $\mathrm{E}_{\mathrm{es}}$, known as end systolic elastance, can be accurately measured non-invasively [104]. $\mathrm{E}_{\mathrm{es}}$ and the slope of EDPVR at low volumes represent the maximum and minimum, respectively, of the time-dependent elastance, $\mathrm{E}(\mathrm{t})$ (Fig. 3E). Typical values for $\mathrm{E}_{\mathrm{es}}$ summarized by Gayat et al.[105] are: $\mathrm{E}_{\mathrm{es}} \sim 2.0 \mathrm{~mm} \mathrm{Hg} / \mathrm{ml}$ in 
Capulli, MacQueen, et al. Fibrous Scaffolds for Building Hearts $\quad$ Last Edited: 11/12/2015

normal hearts, $\mathrm{E}_{\mathrm{es}}<1.0 \mathrm{~mm} \mathrm{Hg} / \mathrm{ml}$ in dilated failing hearts and $\mathrm{E}_{\mathrm{es}} \sim 4.0 \mathrm{~mm} \mathrm{Hg} / \mathrm{ml}$ in hypertrophied hearts.

Myocardial tissue is subjected to significant mechanical strain, often exceeding $20 \%$ between systole and diastole, depending on the location within the left ventricle (Table 6). Increased myocardial stiffness is associated with elevated end diastolic pressure in pressureoverloaded but not volume-overloaded ventricles [106]. Zhang et al. [107] found longitudinal and circumferential strain, as well as strain rate, to be highly correlated with $\mathrm{E}_{\mathrm{es}}$. This suggests that, because these measures reflect chamber elastance and contractility, strain measurements provide added value to ejection fraction in the prediction of adverse outcomes. 
Capulli, MacQueen, et al. Fibrous Scaffolds for Building Hearts ～Last Edited: 11/12/2015

A

\begin{tabular}{cc}
\hline $\begin{array}{c}\text { Quality Assurance } \\
\text { Parameters }\end{array}$ & $\begin{array}{c}\text { Quality Score } \\
\text { (Mature - Engineered) }\end{array}$ \\
\hline Tissue Architecture Subindex \\
Cellular aspect ratio (AU) \\
Sarcomere length ( $\mu \mathrm{m})$ & $7: 1-2: 1$ \\
Global sarcomere alignment (AU) & $2.2-1.6$ \\
Sarcomere packing density (AU) & $0.7-0.4$ \\
\hline Electrophysiology Subindex & $0.22-0.16$ \\
\hline Conduction velocity (cm/s) & $80-25$ \\
Action potential duration (ms) & $350-150$ \\
Maximal upstroke velocity (V/s) & $228-50$ \\
Resting membrane potential (mV) & $-90--60$ \\
\hline Contractility Subindex & \\
Twitch stress (kPa) & $17-0.5$ \\
Time to peak force (ms) & $235-90$ \\
Time to 90\% relaxation (ms) & $309-119$ \\
\hline Composite Quality Score (\%) & 43 \\
\hline
\end{tabular}

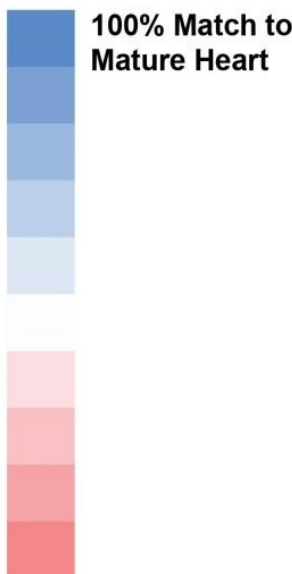

$0 \%$ Match to

Mature Heart

B

\section{Section Key Questions}

2.1 How are the cells of the heart organized?

2.2 What are the electrical properties of the myocardium?

2.3 What are the contractile properties of the myocardium?

2.4 How much strain must the myocardium endure?

2.5 What is the structural organization of cardiac valves?

3.1 How do we design cell scaffolds that match native ECM?

3.2 How do we recapitulate the structure of the myocardium?

4.1 How is the structure of the heart affected by disease?

4.2 How do we achieve electromechanical integration in cardiac patches?

4.3 How do we create scaffolds that promote endogenous growth?

\section{Current State}

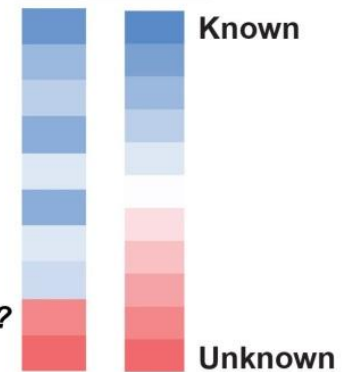

Fig. 1. Quality assessment of engineered tissues. (A) Integration of a combination of structural and functional experimental measurements provides insight into the ability of engineered human stem cell-derived heart tissues to meet design criteria established according to "gold standard" measurements made on mature heart tissues. Calculating a composite quality score by averaging the percent differences between the mature and engineered tissue measurement values could allow comprehensive quantitative comparison [108-112]. (B) To build engineered heart constructs, there are several key questions concerning design aspects that we address in this review. 

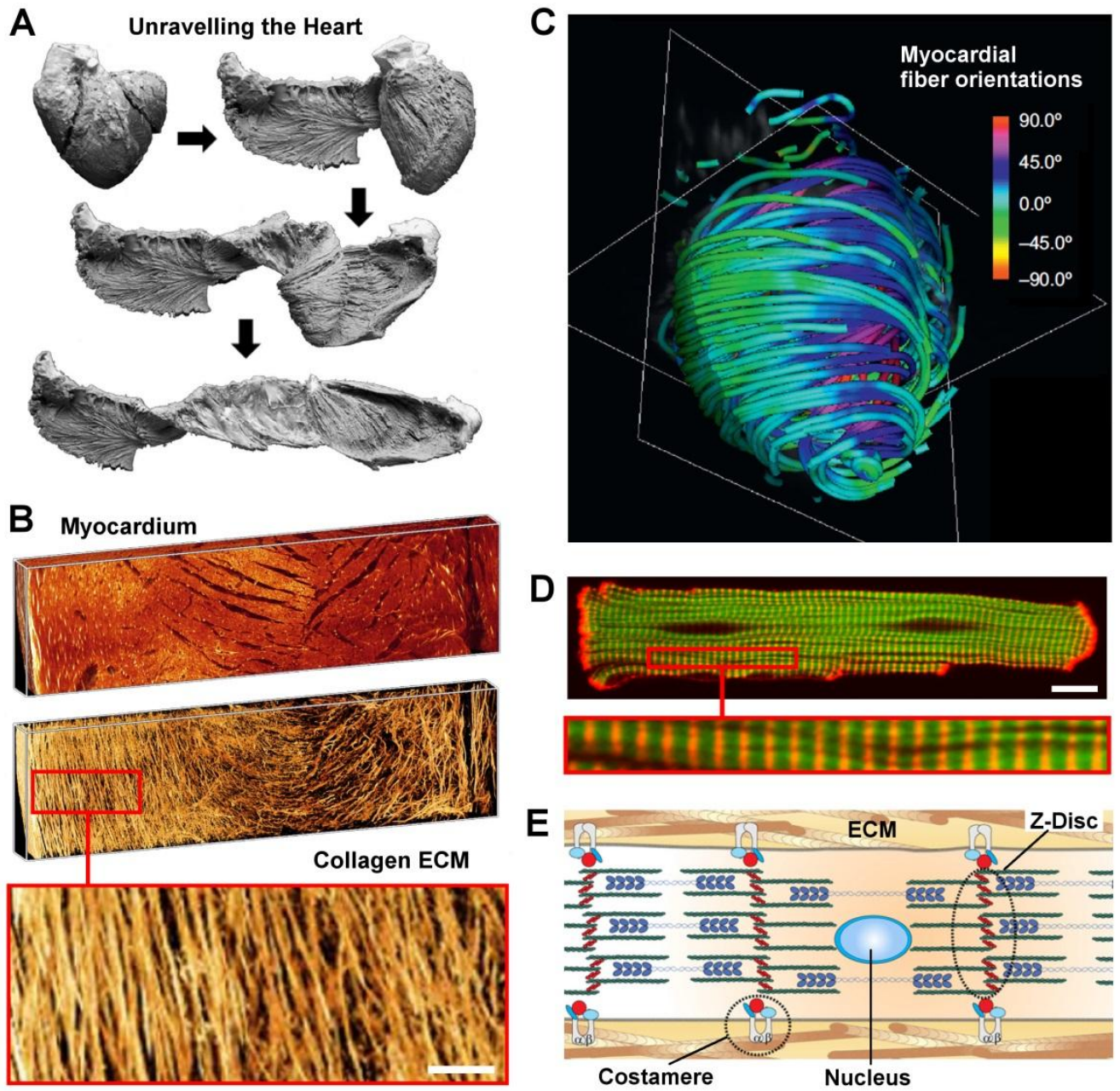

Fig. 2. Multiscale structure of the myocardium. (A) Key phases of a dissection procedure (bovine heart) revealing the laminar architecture of the heart. Reprinted from [47] with permission from Elsevier; (B) Three-dimensional volume renderings of myocardial muscle (top) and collagen structures (bottom) extracted from images of Wistar-Kyoto rat left ventricles (LVs). Inset show fibrillar collagen structure, scale bar $=100 \mu \mathrm{m}$. Reprinted from [50] with permission from the American Physiological Society. (C) Color map of myocradial fiber orientation obtained using diffusion tensor magnetic resonance imaging (DTI). Fullcolor scheme represents fiber orientations, simplified tractography is shown. Adapted from [113] with permission from Elsevier; (D) Confocal fluorescence image of a cardiomyocyte: F-actin (green), $\alpha$-actinin (red), magnified inset shows sarcomeric striations, scale bar $=10 \mu \mathrm{m}$. Reprinted from [114] with permission from Elsevier; (E) Schematic depicting cardiac myofibril organization in vivo. Integrins colocalized to the costamere help mechanically couple the intracellular z-disc to the extra-cellular matrix (ECM). Z-discs anchor the contractile actin-myosin machinery. Adjacent myocytes are coupled to each other via adherens junctions. Reprinted from [2] with permission from Elsevier. 
Table 1. Reference values for the human left ventricle ${ }^{*}$

\begin{tabular}{|l|l|}
\hline Measurement & Normal Range \\
\hline Diastolic diameter & $2.4-3.2 \mathrm{~cm}$ \\
\hline Diastolic volume & $35-75 \mathrm{~mL} / \mathrm{m}^{2}$ \\
\hline Systolic volume & $12-30 \mathrm{~mL} / \mathrm{m}^{2}$ \\
\hline Ejection fraction & $67 \pm 8 \%$ \\
\hline Septal wall thickness & $0.6-1.0 \mathrm{~cm}$ \\
\hline Posterior wall thickness & $0.6-1.0 \mathrm{~cm}$ \\
\hline End-diastolic volume & $70 \pm 20 \mathrm{~mL} / \mathrm{m}^{2}$ \\
\hline End-systole volume & $24 \pm 0 \mathrm{~mL} / \mathrm{m}^{2}$ \\
\hline Systolic pressure & $90-140 \mathrm{mmHg}$ \\
\hline Diastolic pressure & $6-12 \mathrm{mmHg}$ \\
\hline
\end{tabular}

*Values obtained from Otto et al.[115]

Table 2. ECM bioprotein composition of rat hearts*

\begin{tabular}{|c|c|c|c|}
\hline \multirow{2}{*}{ ECM Protein } & \multicolumn{3}{|c|}{ Percent of total ECM Composition } \\
\hline & $\mathrm{Fetal}^{\dagger}$ & Neonatal $^{\S}$ & Adult $^{\text {Tl }}$ \\
\hline Fibronectin & 26 & 21 & 4 \\
\hline Laminin & 0 & 5 & 14 \\
\hline Periostin & 7 & 4 & 1 \\
\hline Collagen-1 & 11 & 16 & 38 \\
\hline Collagen-3 & 0 & 0 & 4 \\
\hline Collagen-4 & 8 & 6 & 5 \\
\hline Collagen-5 & 0 & 6 & 2 \\
\hline Collagen-6 & 11 & 0 & 6 \\
\hline Emilin-1 & 4 & 6 & 0 \\
\hline Fibrillin-1 & 13 & 18 & 18 \\
\hline Fibrillin-2 & 8 & 8 & 0 \\
\hline Perlecan & 12 & 10 & 8 \\
\hline
\end{tabular}

"Values obtained from Williams et al.[116]: Sprague-Dawley rats,

${ }^{\dagger}$ Fetal: Embryonic day 18-19, ${ }^{\S}$ Neonatal: Postnatal day 2-4, ${ }^{\mathbb{I}}$ Adult: $~ 3$ months old

Table 3. Myocardial conduction velocity

\begin{tabular}{|c|c|c|}
\hline & Conduction Velocity $(\mathrm{cm} / \mathrm{sec})$ & Ref. \\
\hline Human LV & $\begin{array}{l}\text { Pacing interval } 1000 \mathrm{~ms}:\left(\mathrm{CV}_{\mathrm{L}}=92 \pm 4, \mathrm{CV}_{\mathrm{T}}=22 \pm 2\right) \\
\text { Pacing interval } 288 \mathrm{~ms}:\left(\mathrm{CV}_{\mathrm{L}}=73 \pm 4, \mathrm{CV}_{\mathrm{T}}=11 \pm 3\right) \\
\mathrm{CV}_{\mathrm{L}}=80 \pm 8, \mathrm{CV}_{\mathrm{T}}=23 \pm 3(\text { epicardial })\end{array}$ & $\begin{array}{l}{[85]} \\
{[85]} \\
{[117]}\end{array}$ \\
\hline Pig LV & $\begin{array}{l}\mathrm{CV}_{\mathrm{L}}=67 \pm 1.9, \mathrm{CV}_{\mathrm{T}}=30 \pm 1, \mathrm{CV}_{\mathrm{N}}=17 \pm 0.4 \\
\mathrm{CV}_{\mathrm{L}}=50 \pm 2, \mathrm{CV}_{\mathrm{T}}=21 \pm 1 \text { (epicardial): After } 3 \text { to } 5 \text { min of } \\
\text { global ischemia, } C V_{\mathrm{L}} \text { and } C \mathrm{CV}_{\mathrm{T}} \text { decreased to approximately } 30 \\
\text { and } 13 \mathrm{~cm} / \mathrm{sec} \text {, respectively }\end{array}$ & $\begin{array}{l}{[86]} \\
{[118]}\end{array}$ \\
\hline Rat LV & $\mathrm{CV}_{\mathrm{L}}=69 \pm 13, \mathrm{CV}_{\mathrm{T}}=33 \pm 6$ & [119] \\
\hline NRVM anisotropic tissues & $\begin{array}{l}\mathrm{CV}_{\mathrm{L}}=34.6+4.5, \mathrm{CV}_{\mathrm{T}}=19.0+4.3, \\
\mathrm{CV}_{\mathrm{L}}=30.5+4.1, \mathrm{CV}_{\mathrm{T}}=13.4+2.7 \text { (Isotropic } \mathrm{CV}=21.2+3.7 \text { ) }\end{array}$ & $\begin{array}{l}120] \\
{[121]}\end{array}$ \\
\hline NRVM muscular thin films & $\begin{array}{l}\text { Isotropic: } \mathrm{CV}_{\mathrm{L}}=15 \pm 5, \mathrm{CV}_{\mathrm{T}}=15 \pm 4 \\
\text { Anisotropic: } \mathrm{CV}_{\mathrm{L}}=20 \pm 7, \mathrm{CV}_{\mathrm{T}}=10 \pm 2\end{array}$ & [10] \\
\hline mESC-CM & $\mathrm{CV}=19.2 \pm 0.4$ & [122] \\
\hline hESC-CM & $\begin{array}{l}\mathrm{CV}=25.1 \text { for } 90 \% \mathrm{CM} \text { purity } \\
\mathrm{CV}=9.76 \pm 1.0 \text { for } 48-65 \% \mathrm{CM} \text { purity }\end{array}$ & [123] \\
\hline
\end{tabular}

Abbreviations: $\mathrm{CV}_{\mathrm{L}}$, longitudinal conduction velocity; $\mathrm{CV}_{\mathrm{T}}$, transverse conduction velocity; $\mathrm{CV}_{\mathrm{N}}$, normal conduction velocity; CM, cardiomyocyte; hESC-CM, human embryonic stem cell derived cardiomyocyte; $\mathrm{LV}$, left ventricle; mESC-CM, mouse embryonic stem cell derived cardiomyocyte; NRVM, neonatal rat ventricular myocyte; SL, sarcomere length. 
Capulli, MacQueen, et al. Fibrous Scaffolds for Building Hearts Last Edited: 11/12/2015

Table 4. Myocardial contractile stress

\begin{tabular}{|c|c|c|}
\hline & Contractile stress $(\mathrm{kPa})$ & Ref. \\
\hline Human LV & 109.5 (remote from MI), 73.1 (adjacent to MI) & [124] \\
\hline Rat LV & $\begin{array}{l}12.1 \pm 0.9(\text { peak of developed stress, } \mathrm{SL}=1.97 \pm 0.01 \mu \mathrm{m}) \\
11.0 \pm 0.8(\text { peak systolic midwall stress })\end{array}$ & $\begin{array}{l}{[125]} \\
{[126]} \\
\end{array}$ \\
\hline Human ventricular muscle strips & Normal, VO: $44 \pm 11.7,19.9 \pm 3.7$ & [127] \\
\hline Rat left ventricular papillary muscles & $56.4 \pm 4.4$ & [127] \\
\hline NRVM-based muscular thin films & Peak: $15.4 \pm 1.4$, Twitch: $12.7 \pm 1.1$ & [128] \\
\hline $\mathrm{hESC}-\mathrm{CM}$ & $11.8 \pm 4.5$ (Force: $5.7 \pm 1.0 \mathrm{nN} /$ cell $)$ & [123] \\
\hline Adult rat $\mathrm{CM}$ & $41.6 \pm 5.6$ & [129] \\
\hline AGVM & $\begin{array}{l}\text { EPI, SL }=1.9:\left(\mathrm{T}_{\text {pass }}, \mathrm{T}_{\max }\right)=0.5 \pm 0.1,25 \pm 4 \\
\text { EPI, } \mathrm{SL}=2.3:\left(\mathrm{T}_{\text {pass }}, \mathrm{T}_{\max }\right)=1.5 \pm 0.2,23 \pm 3 \\
\mathrm{ENDO}, \mathrm{SL}=1.9:\left(\mathrm{T}_{\text {pass }}, \mathrm{T}_{\max }\right)=0.6 \pm 0.1,22 \pm 4 \\
\mathrm{ENDO}, \mathrm{SL}=2.3:\left(\mathrm{T}_{\text {pass }}, \mathrm{T}_{\max }\right)=2.4 \pm 0.2,20 \pm 3\end{array}$ & [94] \\
\hline \multicolumn{3}{|c|}{$\begin{array}{l}\text { Abbreviations: AGVM, adult guinea pig ventricular myocytes; CM, cardiomyocyte; ENDO, endocardial; EPI, } \\
\text { epicardial; hESC-CM, human embryonic stem cell derived cardiomyocyte; LV, left ventricle; mESC-CM, mouse } \\
\text { embryonic stem cell derived cardiomyocyte; MI, myocardial infarction; NRVM, neonatal rat ventricular } \\
\text { myocyte; SL, sarcomere length; } \mathrm{T}_{\text {pass }} \text {, passive tension; } \mathrm{T}_{\max }, \text { maximum tension; VO, volume overload }\end{array}$} \\
\hline
\end{tabular}

Table 5. Myocardial stiffness

\begin{tabular}{|c|c|c|}
\hline & Stiffness Modulus (kPa) & Ref. \\
\hline Human LV & $\begin{array}{l}\mathrm{ES}=18.3 \pm 4.1, \mathrm{ED}=15.0 \pm 3.2(\text { assuming } \mathrm{E}=3 \mu) \\
\mathrm{ED}: 24.9 \pm 2.2\end{array}$ & $\begin{array}{l}{[130]} \\
{[131]}\end{array}$ \\
\hline Pig LV & $\mathrm{ES}=28.0 \pm 5.7, \mathrm{ED}=18.1 \pm 5.6($ assuming $\mathrm{E}=3 \mu)$ & [103] \\
\hline Human ventricular muscle strips & $\begin{array}{l}\text { PO, VO: } 137.2,51.4(\text { extension }=0.05) \\
\text { PO, VO: } 85.5,18.8(\text { extension }=0.2)\end{array}$ & [106] \\
\hline $\begin{array}{l}\text { Human ventricular muscle, filament- } \\
\text { extracted strips }\end{array}$ & $\begin{array}{l}\text { PO, VO: } 28.1,10.7(\text { extension }=0.05) \\
\text { PO, VO: } 97.8,43.6(\text { extension }=0.2)\end{array}$ & [106] \\
\hline $\begin{array}{l}\text { Adult human CM obtained from } \\
\text { endocardial ventricular biopsies }\end{array}$ & $\begin{array}{l}\text { PO, Normal, VO: } 154.6,59.1,20.7(\text { extension }=0.05) \\
\text { PO, Normal, VO: } 90.3,47.8,46.8(\text { extension }=0.2)\end{array}$ & [106] \\
\hline
\end{tabular}

Abbreviations: CM, cardiomyocyte; E, elastic modulus; ED, end-diastolic; ES, end-systolic; LV, left ventricle; $\mathrm{PO}$, pressure overload; VO, volume overload; $\mu$, shear modulus.

Table 6. Strain in the human left ventricle (LV)

\begin{tabular}{|l|c|}
\hline \multicolumn{1}{|c|}{ Strain values } & Ref. \\
\hline $\begin{array}{l}\text { Average peak shortening in the } \mathrm{LV} \text { at } \\
\text { endocardium, midwall, epicardium }\end{array}$ & \\
\hline $44 \% \pm 6,30 \% \pm 6,22 \% \pm 5$ & {$[132]$} \\
\hline $32 \% \pm 4,23 \% \pm 4,16 \% \pm 4$ & {$[133]$} \\
\hline $\begin{array}{l}\text { Peak shortening at the middle ventricular level about } \\
\text { the circumference }\end{array}$ & \\
\hline $15 \% \pm 4$ to $19 \% \pm 5$ & {$[134]$} \\
\hline $18 \% \pm 3$ to $26 \% \pm 3$ & {$[133]$} \\
\hline $\begin{array}{l}\text { Longitudinal peak shortening about the middle LV } \\
\text { circumference at midwall }\end{array}$ & \\
\hline $12 \% \pm 5$ to $13 \% \pm 6$ & {$[134]$} \\
\hline $16 \% \pm 3$ to $18 \% \pm 3$ & {$[133]$} \\
\hline
\end{tabular}


A Cardiomyocyte coupling
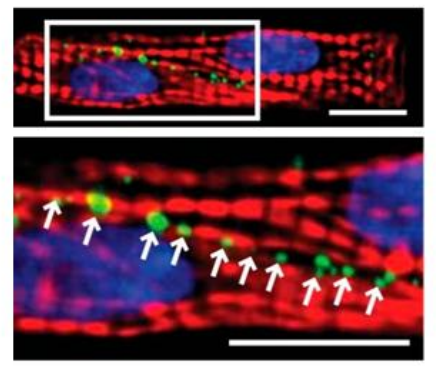

B

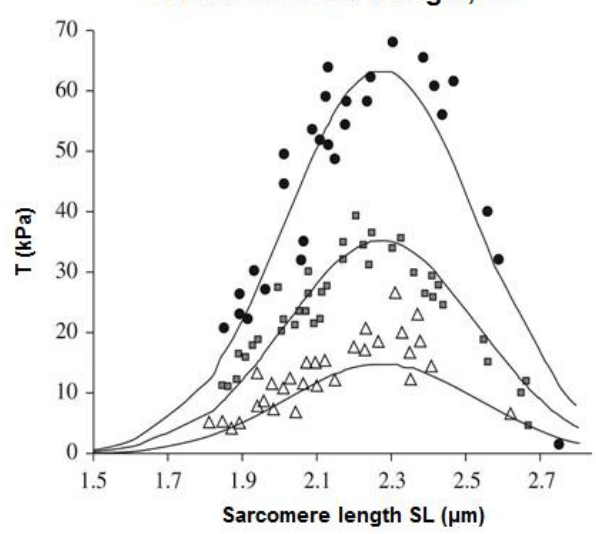

D

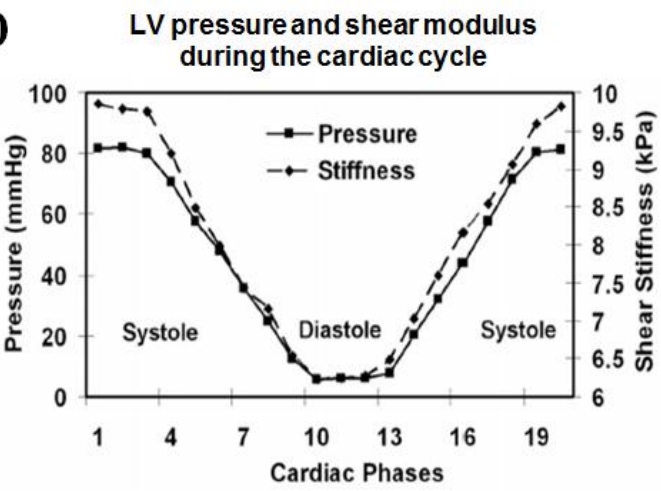

C
Engineered cardiac tissue
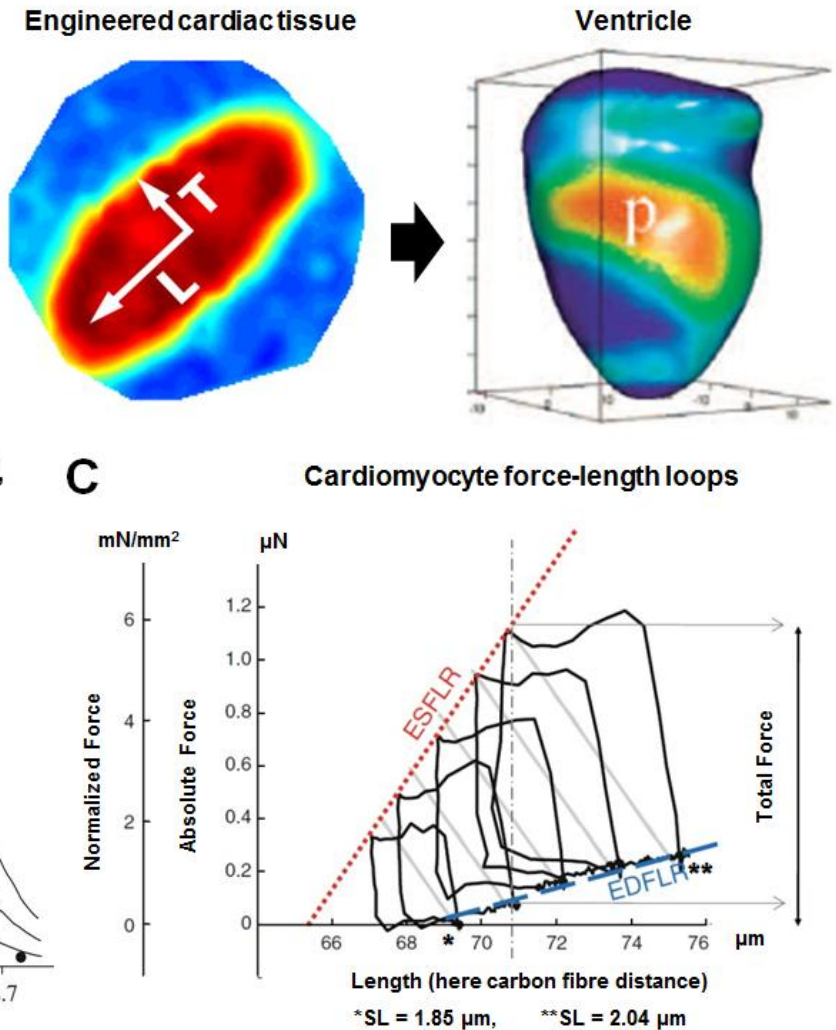

E

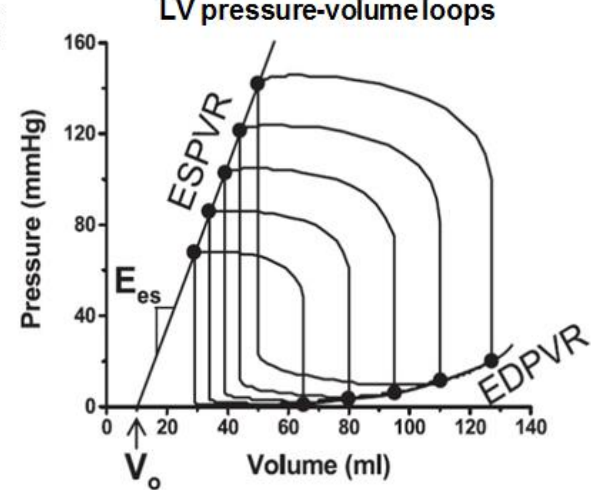

Fig. 3. Multiscale electromechanical properties of the myocardium. (A) Left: Coupling between cardiomyocytes through specialized gap junctions (green: Cx43, red: actin, blue: nuclei). Adapted from [101] with permission from the National Academy of Sciences; Middle: anisotropic conduction in a patterned engineered cardiac tissue construct. Reprinted from [135] with permission from the National Academy of Sciences; Epicardial action potential texture mapping during epicardial pacing of a rabbit heart at location, p. Adapted from [136] with permission from the international society for optics and photonics; (B) Mechano-chemical couplings driving cardiomyocyte contraction modelled in silico (solid lines), fitting experimental data obtained by Weiwad et al. [137], highlighting the SL-active tension relationship for skinned cardiac cells activated in solutions with increasing $\mathrm{Ca}^{2+}$ concentrations. Filled circles, $\mathrm{pCa}=4.9$; filled squares, $\mathrm{pCa}=5.46$; open triangles, $\mathrm{pCa}=5.7$. Reprinted from [138] with permission from the Royal Society; (C) Diagram representing end-diastolic and end-systolic force-length relations (EDFLR and ESFLR, respectively) of a Guinea pig intact isolated ventricular cardiomyocyte. The EDFLR (dashed line, blue) is obtained by monitoring passive tension (force required to arrive at different pre-loads), while ESFLR (dotted line, red) is constructed by recording total force at the end of contractions, initiated from a range of different pre-loads (here covering a sarcomere length, SL, range from 1.85 to $2.05 \mu \mathrm{m}$ ). Reprinted from [98] with permission from Springer; (D) Plots of time-dependent ventricular pressure and stiffness during the cardiac cycle, measured in a healthy adult pig's left ventricle. The myocardium is stiffer in systole than in diastole. Reprinted from [103] with permission from Wiley; (E) Use of intra-ventricular pressure-volume loops to estimate the endsystolic pressure-volume relationship (ESPVR). The linear ESPVR is characterized by a slope ( $\mathrm{E}_{\mathrm{es}}$ ) and a volume axis intercept $\left(\mathrm{V}_{\mathrm{o}}\right)$. In contrast, the diastolic pressure-volume points define a nonlinear end-diastolic pressure/volume relationship (EDPVR). Reprinted from [102] with permission from the American Physiological Society. 


\subsection{Cardiac Valve Structure}

Cardiac valves maintain unidirectional blood flow through the heart by coordinated action of thin membranous structures known as leaflets or cusps. Key structural and functional properties of the cardiac valves are summarized in Table 7. Valve tissue undergoes significant remodeling throughout life and in response to environmental stimuli [139]. However, aberrant valve remodeling can lead to valvular diseases that alter blood flow and mechanical loads placed on the myocardium, ultimately disrupting broad aspects of cardiac function [140, 141]. During the cardiac cycle, increased or decreased left ventricular pressure in systole or diastole, respectively, force the aortic valve leaflets to open and close (Fig. 4A), a process that is repeated $\sim 3$ billion times over the course of an average lifetime [142]. Aortic valve leaflets contain three layers with collagen fibers predominant in the fibrosa, a GAG-rich matrix in the spongiosa, and elastin sheets in the ventricularis [143]. Collagen fibers within the valve leaflets are load bearing during diastole (closure) and oriented principally in the circumferential direction. Elastin fibers are responsible for leaflet recoil during systole (opening) and are principally oriented in the radial direction of the leaflet (Fig. 4B). Disoriented ECM fibers are a hallmark of valve disease (Fig. 4A) although their exact orientation and bundle size is distinctive to each leaflet (Fig. 4C). To study the effects of collagen fiber alignment on valve kinematics and hemodynamics, Marom et al. [144] used numerical fluid-structure interaction models of asymmetric mapped collagen fiber networks from measurements of porcine valve and a simplified-symmetric network (Fig. 4C). They showed that fibers carried most of the mechanical load and asymmetric internal structure had a considerable impact on the hemodynamics. Regions with less dense fiber network were subjected to higher internal stress and flow shear stress magnitudes and, therefore, are at higher risk of damage. Numerous attempts have been made to fabricate tissue engineered 
scaffolds that recapitulate the structure and function of native heart valves [169, 217-219]. By constructing the trileaflet global structure of semilunar valves using fibrous material, in vitro cell seeding allows for physiologically-relevant conditioning that provides structural and mechanical cues for tissue formation before implantation.

Cardiac valves exhibit pronounced structure-function relationships that are often disrupted in valvular heart disease (VHD) and result in abnormal valve leaflet number, morphology, mechanical properties, and/or biochemical composition [145-147]. For example, calcific aortic valve disease initiation is associated with fibrotic collagen accumulation and disorientation, which leads to thickened, stiffened valve leaflets and a deterioration in function [148]. Valve leaflets contain valvular interstitial cells (VIC) and the leaflets are coated by a monolayer of valvular endothelial cells (VEC) that are in contact with circulating blood. VICs are associated with remodeling and repair [149] but their dysregulation can lead to leaflet fibrosis and calcification that progress to sclerosis and stenosis [140, 150]. VECs suppress VIC pathological differentiation into $\alpha$-SMA positive myofibroblasts, an effect that is enhanced by exposure of the endothelium to flow-induced shear stress [151]. VECs also undergo endothelialmesenchymal transformations during valve development and may replenish VIC populations [152]. For these reasons, there is hope that endothelial cell recruitment to valve scaffolds can lead to functional VEC leaflet coating and EMT-based repopulation of interstitium. Because circulating endothelial progenitors are rare [153], a strategy based on endothelial recruitment from vascular structures adjacent to the implanted scaffold seems favorable. Fibrous scaffolds may provide structural cues required to initiate endothelial cell recruitment either from circulating blood or from the border zone adjacent to implanted scaffolds. Fibrous scaffolds may 
provide structural cues required to initiate endothelial cell recruitment and serve as a substrate to recapitulate the valve interstitium for VIC regulation.

Table 7. Human valve properties

\begin{tabular}{|c|c|c|}
\hline Parameter & Values & Ref. \\
\hline \multicolumn{3}{|c|}{ Mechanical Properties } \\
\hline $\begin{array}{l}\text { Native Biaxial Aortic } \\
\text { Valve Stiffness }\end{array}$ & $\begin{array}{l}\text { CIRCUMFRENTIAL }(\mathrm{kPa}) \\
\text { Low-Strain }(0-18 \%): 89.1 \pm 4.63 \\
\text { Mid-Strain }(18-28 \%): 825.11 \pm 29.19 \\
\text { High Strain }(28-35 \%): 1577.17 \pm 53.69 \\
\\
\text { RADIAL (kPa) } \\
\text { Low-Strain }(0-18 \%): 33.94 \pm 1.37 \\
\text { Mid-Strain }(18-28 \%): 116.43 \pm 4.15 \\
\text { High Strain }(28-35 \%): 324.93 \pm 9.84\end{array}$ & {$[154]$} \\
\hline $\begin{array}{l}\text { Native Biaxial Pulmonary } \\
\text { Valve Stiffness }\end{array}$ & $\begin{array}{l}\text { CIRCUMFRENTIAL }(\mathrm{kPa}) \\
\text { Low-Strain }(0-18 \%): 11.31 \pm 0.79 \\
\text { Mid-Strain }(18-28 \%): 408.23 \pm 18.34 \\
\text { High Strain }(28-35 \%): 1457.19 \pm 58.1 \\
\text { RADIAL }(\mathrm{kPa}) \\
\text { Low-Strain }(0-18 \%): 11.67 \pm 0.61 \\
\text { Mid-Strain }(18-28 \%): 50.16 \pm 2.01 \\
\text { High Strain }(28-35 \%): 172.44 \pm 5.24 \\
\end{array}$ & {$[154]$} \\
\hline Load Durability & 40 million loading cycles/year, 3 billion loading cycles/life & [155] \\
\hline $\begin{array}{l}\text { Aortic Valve Flow Rate } \\
\text { (systole, healthy) }\end{array}$ & $\begin{array}{l}1.35 \pm .035 \mathrm{~m} / \mathrm{s} \\
\text { (highest flow rate of valves) }\end{array}$ & {$[156]$} \\
\hline $\begin{array}{l}\text { Mitral Valve Flow Rate } \\
\text { (diastole, healthy) }\end{array}$ & $0.89 \pm 0.15 \mathrm{~m} / \mathrm{s}$ & [157] \\
\hline $\begin{array}{l}\text { Pulmonary Valve Flow } \\
\text { Rate (systole, healthy) }\end{array}$ & $0.6-0.9 \mathrm{~m} / \mathrm{s}$ & {$[158]$} \\
\hline $\begin{array}{l}\text { Tricuspid Valve Flow Rate } \\
\text { (diastole, healthy) }\end{array}$ & $\begin{array}{l}0.7 \mathrm{~m} / \mathrm{s} \\
\text { (lowest flow rate of valves) }\end{array}$ & [159] \\
\hline $\begin{array}{l}\text { Max Closing Strain Rate } \\
\text { (diastole, loaded) }\end{array}$ & Peak Strain Rate: $1000 \% / \mathrm{s}$ & {$[160]$} \\
\hline $\begin{array}{l}\text { Peak Tension Values } \\
\text { (general valve tissue range) }\end{array}$ & Peak Loading Range: 50-100 N/m & {$[161]$} \\
\hline $\begin{array}{l}\text { Transvalvular Pressures } \\
\text { (back pressures) }\end{array}$ & $\begin{array}{l}\text { Aortic Valve: } 80 \mathrm{mmHg} \\
\text { Pulmonary Valve: } 10 \mathrm{mmHg} \\
\text { Mitral Valve: } 120 \mathrm{mmHg} \\
\text { Tricuspid Valve: } 25 \mathrm{mmHg} \\
\end{array}$ & {$[161]$} \\
\hline $\begin{array}{l}\text { Valve Area } \\
\text { Normal }\end{array}$ & $\begin{array}{l}\text { Aortic Valve: } 4.6 \pm 1.1 \mathrm{~cm}^{2} \\
\text { Mitral Valve: } 7.8 \pm 1.9 \mathrm{~cm}^{2} \\
\text { Pulmonary Valve: } 4.7 \pm 1.2 \mathrm{~cm}^{2} \\
\text { Tricuspid Valve: } 10.6 \pm 2.6 \mathrm{~cm}^{2}\end{array}$ & [115] \\
\hline $\begin{array}{l}\text { Shear on Aortic Valve } \\
\text { (aortic surface, systole) }\end{array}$ & $20 \mathrm{dyn} / \mathrm{cm}^{2}$ & {$[162]$} \\
\hline \multicolumn{3}{|c|}{ ECM Properties } \\
\hline $\begin{array}{l}\text { Endothelial Cells } \\
\text { (stain and western) }\end{array}$ & $\begin{array}{l}\text { Morphology: Characteristic cobblestone morphology in vitro } \\
\text { Immunohistochemistry and Western: } \\
\text { 1) vWF- granular and perinuclear } \\
\text { 2) Vimentin- uniform distribution } \\
\text { 3) DAPI- large and rounded nuclei } \\
\text { No Staining: } \\
\text { 1) } \alpha \text { SMA } \\
\text { 2) Myosin and desmin }\end{array}$ & $\begin{array}{l}{[163]} \\
{[161]}\end{array}$ \\
\hline
\end{tabular}




\begin{tabular}{|c|c|}
\hline $\begin{array}{l}\text { Interstitial Cells } \\
\text { (stain and western) }\end{array}$ & $\begin{array}{l}\text { Morphology: Mixture of spindle and rhomboid shaped cells, } \\
\text { rapid proliferation in vitro } \\
\text { Immunohistochemistry and Western: } \\
\text { 1) Vimentin- strong and uniform distribution (fresh } \\
\text { \& culture) } \\
\text { 2) } \alpha \text { SMA- strong staining (in culture, not fresh) } \\
\text { 3) DAPI- large and rounded nuclei } \\
\text { 4) Weaker stains for myosin, calponin, and h- } \\
\text { caldesmon (not seen in fresh explants) } \\
\text { No Staining: } \\
\text { 1) Desmin } \\
\text { 2) vWF }\end{array}$ \\
\hline $\begin{array}{l}\text { Native Matrix } \\
\text { Composition (histology) }\end{array}$ & 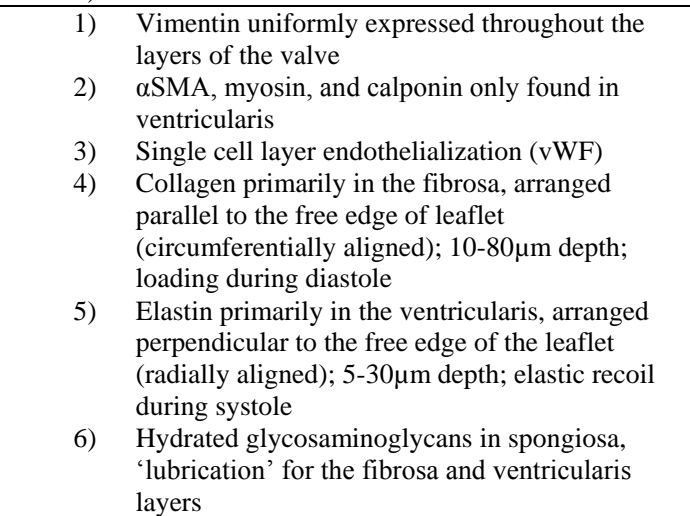 \\
\hline
\end{tabular}



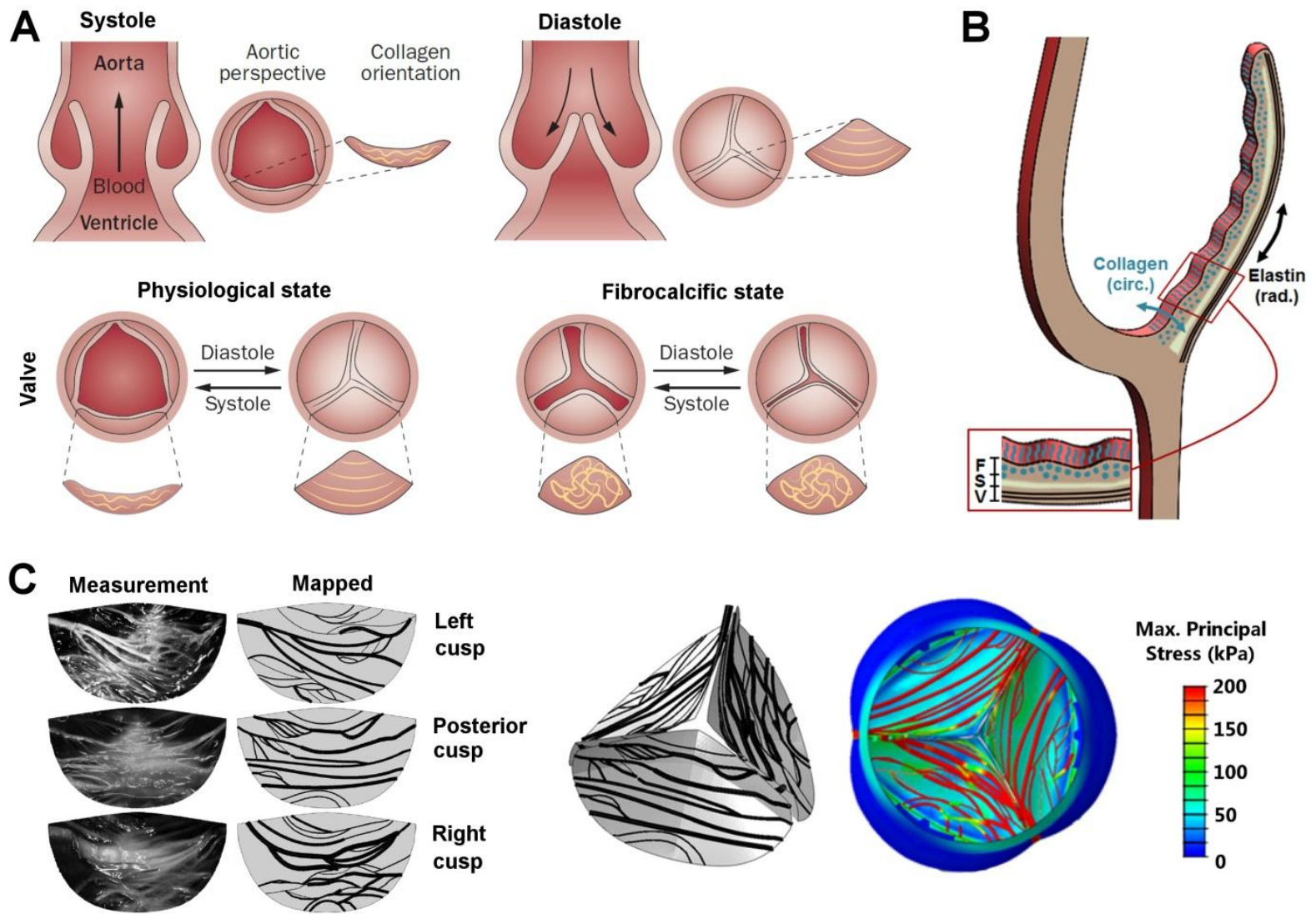

Fig. 4. Structure of the aortic valve in health and disease. (A) Schematic description of a healthy aortic valve. Systolic contraction of the left ventricle forces the aortic valve leaflets to open, allowing blood to enter the aorta. The reversed pressure gradient, created when the heart rests in diastole, causes the aortic valve leaflets to close, preventing retrograde blood flow into the heart. Circumferential collagen alignment allows the leaflets to stretch in the radial direction while providing the tensile strength required to prevent leaflet prolapse. Loss of ECM organization associated with fibrocalcific diseased state. Reprinted from[148] with permission from Macmillan Publishers Limited; (B) Schematic crosssectional view of a valve leaflet showing fibrosa, F, spongiosa, S, and ventricularis, V, layers. Circumferential collagen alignment in the fibrosa and radial elastin alignment in the ventricularis are indicated; (C) Left: Stretched cusps and the mapped collagen fiber network. Right: A 3D view from the aortic side of collagen fiber maps and associated maximum principal stress contours plotted on the deformed structure during diastole. Reprinted from[144] with permission from ASME. 
Capulli, MacQueen, et al. Fibrous Scaffolds for Building Hearts $\quad$ Last Edited: 11/12/2015

\section{Fibrous Scaffold Production Techniques}

Nanofibers with high surface area to volume ratios and small diameters mimic ECM structure, thus providing suitable substrates for regenerative tissue growth. Three prominent nanofiber scaffold production methods are illustrated in Fig. 5 including decellularization of tissues (Fig. 5A), electrospinning (Fig. 5B), and Force Spinning (Fig. 5C). The respective advantages and disadvantages of these methods are outlined in Table 8 , and properties of fibrous scaffolds produced by these methods are listed in Table 9. Structural properties such as fiber diameter size, thickness, and porosity are tuned in these scaffolds to allow cellular integration and tissue formation. The biomechanical composition of scaffolds is tailored to recapitulate the native tissue chemistry and mechanics as instructive cues for specific tissue formation. For example, heart valve tissue scaffold porosity must be tuned to allow cell infiltration but limit vascularization while an elastic material (i.e. elastin) oriented radially will provide scaffold recoil and a strong material (i.e. collagen) oriented circumferentially will provide structural integrity. Although decellularized tissues and organs provide 3D substrates for tissue regeneration, the lack of experimental control over constituent components hinders reproducibility of scaffold composition and reduces predictability of cell response to the scaffold. Emerging fiber production techniques aim to overcome these limitations using a "bottom-up" approach to scaffold engineering where each scaffold component (e.g., ECM bioproteins) and structure is precisely controlled. 


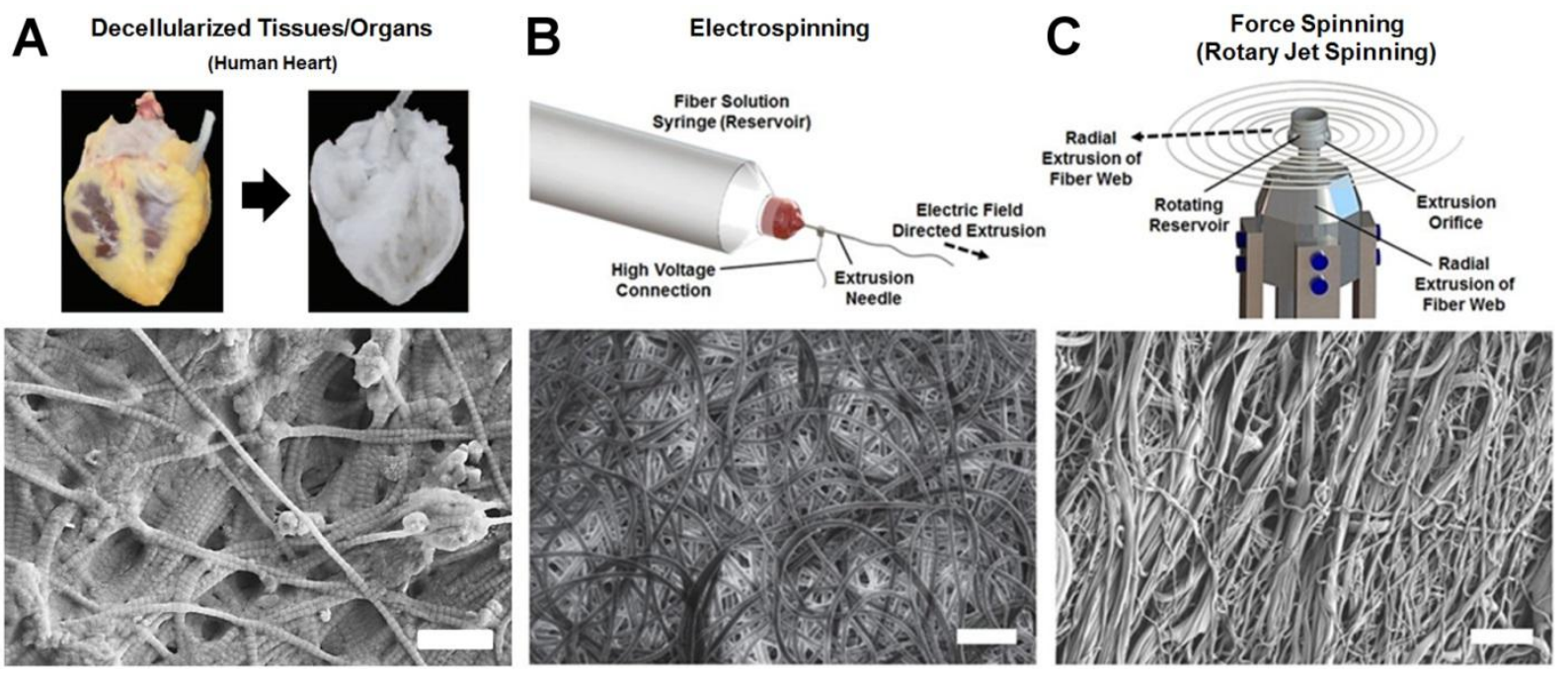

Fig. 5. Strategies for building fibrous scaffolds. (A)Decellularized human heart (top), reprinted from [164] with permission from Elsevier, and decellularized porcine submucosa (bottom), scale bar is $500 \mathrm{~nm}$. (B) Electrospun fibrous use high voltages to extrude conductive fiber precursors, scale bar is $30 \mu \mathrm{m}$, reprinted from [165] with permission from Istituto Superiore di Sanità. (C) Force spinning methods such as rotary jet spinning adopt many of the benefits of electrospinning while scaling up production levels and expanding material diversity, scale bar is $30 \mu \mathrm{m}$.

Table 8. Scaffold Fabrication Techniques

\begin{tabular}{|c|c|c|}
\hline $\begin{array}{c}\text { Scaffold Fabrication } \\
\text { Technique }\end{array}$ & Design Advantages & Manufacturing Limitations \\
\hline $\begin{array}{l}\text { Decellularized Tissues } \\
\text { and Organs }\end{array}$ & $\begin{array}{l}\text { - } \quad \text { Purely extracellular matrix } \\
\text { - } \quad \text { Exact multiscale structure }\end{array}$ & $\begin{array}{ll}\text { - } & \text { Immature cells within a mature matrix } \\
\text { - } & \text { Non-uniform decellularization protocols } \\
\text { - } & \text { Lack of standards for successful } \\
\text { - } & \text { decellularization } \\
\text { - } & \text { Variable sample composition } \\
\end{array}$ \\
\hline Electrospinning & $\begin{array}{l}\text { - Diversity of materials and solvents } \\
\text { - Control of fiber morphology (nano to } \\
\text { macro) }\end{array}$ & $\begin{array}{l}\text { - } \quad \text { Requires conductive polymers and solvents } \\
\text { - } \quad \text { Reliance on high voltage for fiber formation } \\
\text { - } \quad \text { Reproduction rates } \\
\text { environmental control }\end{array}$ \\
\hline $\begin{array}{l}\text { Force Spinning } \\
\text { (Rotary Jet Spinning) }\end{array}$ & $\begin{array}{ll}\text { - } & \text { Diversity of materials and solvents } \\
\text { - } & \text { Control of fiber morphology (nano to } \\
\text { macro) } \\
\text { - } & \text { Nano-micro scale fiber fabrication } \\
\text { - } & \text { Moderate production rate }\end{array}$ & $\begin{array}{l}\text { - Reproducible fiber production requires } \\
\text { environmental control }\end{array}$ \\
\hline
\end{tabular}




\subsection{Decellularized Extracellular Matrix Fibrous Scaffolds}

The decellularization of allogeneic or xenogeneic tissues may be the most structurally and compositionally relevant method to fabricate fibrous scaffolds for regenerative tissue engineering (Fig. 5A). A fully decellularized tissue, in theory, will retain the fibrous, three dimensional structure and organization of its constituent protein ECM providing the exact scaffolding framework of a specific organ [166]. Decellularizing tissues is rooted in the successes of transplanted cadaveric and donor tissues; by further removing the native cells of a transplant tissue, the aim is to avoid the risk of rejection and be able to "customize" the tissue with a different native or stem cell based population of cells [164]. Physical, chemical and enzymatic treatments are used to decellularize tissues [167, 168], including lungs [169], kidneys [170], heart [171], bone [172], and vasculature [173]. Recently, a detergent based treatment protocol using both antegrade and retrograde perfusion through the native tissue vasculature at low relative physiological pressures was published for the effective decellularization of whole hearts, lungs, and kidneys [174]. The maintained vasculature of decellularized tissues provides not only the necessary access to the tissue for decellularization, but also serves as a recellularization conduit and nutrient transport system in the regenerating tissue. Reseeded, whole heart scaffolds produced by perfusion methods have even been shown to develop immature organ-level function in vitro such as electrical conduction and mechanical function (pumping/contraction) of the reseeded heart $[175,176]$. The return of some organ level function demonstrates that decellularized tissues may provide a viable source of fibrous scaffold with the architectural and compositional cues necessary to potentiate tissue regeneration.

Although decellularized tissues and organs can provide fibrous scaffolds that resemble native structure and biochemical composition, matching these properties to specific patient needs 
Capulli, MacQueen, et al. Fibrous Scaffolds for Building Hearts $\quad$ Last Edited: 11/12/2015

is challenging. The matrix necessary and sufficient to activate immature resident stem cell populations and regulate the development of these cells into mature tissues remains unclear and is not controlled experimentally when using developmentally mature decellularized tissues. Furthermore, there exist many unique processing methods that attempt to sufficiently decellularize the tissue while minimizing ECM deterioration and aberrant host inflammatory responses $[177,178]$. This diversity in the field has resulted in a lack of minimum standards for determining successful decellularization and host reactions to organ- or tissue-based fibrous scaffolds [167].

\subsection{Synthetically Produced Fibrous Scaffolds}

Synthetic fibrous scaffold production and evaluation can be subject to higher degrees of manufacturing control than tissue decellularization. This lends itself to the introduction of good manufacturing procedures and increased reproducibility and reliability. The most popular method of fabricating nanofiber scaffolds via synthetic engineering is electrospinning (Fig. 5B). Electrospinning is the process by which an electrically charged polymer melt or solution is extruded through an orifice, creating a jet that solidifies into nanofibers that are subsequently collected on a substrate [179]. Numerous methods now exist to electrospin nanofibers, including traditional needle arrays and needle-free techniques [25, 26] developed to improve fiber formation and production rates: these include bubble electrospinning [180] and microfluidic electrospinning [181]. Synthetic polymers and biological proteins are electrospun using these techniques independently $[182,183]$ or in combination $[184,185]$. The diversity of electrospinning techniques and electrospun materials has translated to numerous fibrous tissue 
engineering applications including ligament, tendon, skeletal muscle, skin, blood vessel, and neural scaffolding [186].

The diversity of electrospinning techniques and applications result from controlled engineering design and fabrication processes. Unlike decellularized tissue scaffolds manufactured using top-down approaches, synthetic electrospun scaffolds are built "bottom-up." Because of this "bottom-up" approach, scaffold characteristics such as fiber diameter [187], fiber alignment [26], scaffold porosity for cell infiltration [188], and macroscopic scaffold geometry [189] can be controlled by simply varying needle diameter, applied needle voltage, flow rate or viscosity of solution/melt, along with a number of other spinning parameters [190]. In addition to control over these physical characteristics, electrospun scaffolds can be bioactively functionalized with the inclusion of drugs [191] or specific growth factors [192] within the fibers to guide host response and endogenous repair mechanisms. Recently, electrically conductive fibers [193] and metabolic sensors [194, 195] have been incorporated into 'smart' electrospun scaffolds for real-time tissue performance monitoring. Since electrospun fibers are built by a "bottom-up," fiber-by-fiber approach, they can be biomechanically tuned and functionalized for specific tissue scaffolding.

However, it is also this fiber-by-fiber approach to creating scaffolds with electrospinning that limits its utility as a manufacturing method. Production rates of electrospun fibers are very low compared to industrial fiber production techniques; the most productive industrial scale electrospinning systems hardly reach kilograms of fibers per hour whereas common industrial scale melt or wet spin fiber production can reach tens of tons of fibers per hour [196]. Although numerous multi-needle setups have been developed to increase fiber production rates [197], these methods complicate the normally simple electrospinning setup which makes it an attractive 
manufacturing technique by introducing multiple electric fields and numerous high voltage connections. Additionally, because of this high voltage required to electrospin, material and solvent choice for electrospinning is limited to polymers that are soluble in conductive solvents. This is particularly restrictive for electrospinning regenerative scaffolds made of or including protein due to the detrimental effects of voltage and solvent on protein three dimensional structure [198]. Melt-electrospinning processes have been developed to address the limitations of solvents [199], though the resultant fibers generated are commonly on the order of microns in diameter and the high temperature of the melt process likely has a denaturing effect on electrospun proteins and stability of synthetic polymers. Production rate and material manufacturing limitations have limited the translation of electrospun fibrous scaffolds to industrial-scale production.

In order to overcome the manufacturing limitations of electrospinning, force-based fiber fabrication via Rotary Jet Spinning (RJS) [28] was developed for the fabrication of fibrous scaffolds (Fig. 5C). RJS uses the centrifugal forces developed in a rotating reservoir perforated with a single or multiple micron-scale orifices to circumferentially extrude nanofibers from solution. By varying polymer solution and spinning parameters (e.g. solution viscosity, rotation rate and extrusion speed), nanofiber properties such as fiber diameter and alignment can easily be controlled using the RJS fabrication technique [200]. Production rates achievable by a single force driven system $(\sim 100 \mathrm{~g} / \mathrm{hr})$ are roughly two orders of magnitude higher than similarly scaled electrospinning systems. Collagen and gelatin nanofibers are rapidly fabricated with the RJS both with and without mixing with synthetic polymers to tune mechanical properties and degradation profiles of scaffolds [29]. In addition to collagen and gelatin, the high shear forces developed in the orifice of the RJS reservoir during extrusion has been exploited to initiate 
Capulli, MacQueen, et al. Fibrous Scaffolds for Building Hearts $\quad$ Last Edited: 11/12/2015

fibrillogenesis of beta sheet rich proteins such as silk to produce insoluble, pure protein nanofibers without the need of post-processing crosslinking [201]. Overcoming the production rate limitations of electrospinning while maintaining, and even increasing, the versatility of spinning materials, RJS and similar force spinning techniques [202] bring synthetic nanofiber based scaffold fabrication processes closer to true manufacturing and clinical translation.

The challenge of any synthetic fiber fabrication technology is building the global, three dimensional structure of the target cardiac tissue; that is, the three dimensional collection of fibers. Because of the "bottom-up" approach of synthetic fibrous scaffold fabrication, building from the nano and micron scales of single fibers to the macro-scale geometries of scaffold tissues requires innovative, cumulative fiber collection techniques. Using electrically grounded plates, cylindrical mandrels, and other specially shaped columnar collectors for example, various geometries can be manufactured via electrospinning fibers to achieve specific tubular fibrous structures. These innovative fiber collection strategies suggest that full multiscale recapitulation of tissue and organ structures will soon be possible using nanofiber production platforms such as electrospinning and force spinning. 
Table 9. Properties of fibrous scaffolds used in cardiac tissue engineering

\begin{tabular}{|c|c|c|c|c|}
\hline $\begin{array}{l}\text { Manufacturing } \\
\text { Method }\end{array}$ & Composition & Key Scaffold Properties & Application & Ref. \\
\hline Decellularization & $\begin{array}{l}\text { Decellularized } \\
\text { porcine } \\
\text { myocardium }\end{array}$ & $\begin{array}{l}\text { - Thickness: } 2.27 \pm 0.38 \mu \mathrm{m} \\
\text { - Surface Area: } 577.45 \pm 44.5 \mathrm{~mm}^{2} \\
\text { - Pore Size: } 21.4 \pm 16.8 \mu \mathrm{m} \\
\text { - Proteins Maintained: collagen and elastin } \\
\text { - Trapped Water Content: } 90.21 \pm 2.36 \% \\
\text { - Stiffness: } 9.5 \pm 1.5 \mathrm{MPa} \text { in fiber direction and } \\
3.3 \pm 0.8 \mathrm{MPa} \text { in cross fiber direction }\end{array}$ & Cardiac tissue engineering & [203] \\
\hline Decellularization & $\begin{array}{l}\text { Decellularized } \\
\text { porcine } \\
\text { myocardium }\end{array}$ & $\begin{array}{l}\text { - Pore Size: } 19.5 \pm 17.9 \mu \mathrm{m} \\
\text { - Thickness: } 2 \mathrm{~mm} \\
\text { - Vasculature: } \varnothing 100-400 \mu \mathrm{m} \\
\text { - Decell Stiffness: } 5.2 \pm 1.7 \mathrm{MPa} \\
\text { - Recell Stiffness: } 760.6 \pm 69.7 \mathrm{kPa}\end{array}$ & $\begin{array}{l}\text { Thick cardiac patch tissue } \\
\text { engineering }\end{array}$ & [204] \\
\hline Decellularization & $\begin{array}{c}\text { Decellularized } \\
\text { porcine aortic } \\
\text { valve }\end{array}$ & $\begin{array}{l}\text { - Proteins Maintained: fibronectin, vWF, } \\
\text { collagen, GAGs present but reduced } \\
\text { - Circ. Elastin Stiffness: } 763 \pm 219 \mathrm{kPa} \\
\text { - Circ. Collagen Stiffness: } 21 \pm 9.3 \mathrm{MPa} \\
\text { - Rad. Elastin Stiffness: } 352 \pm 65 \mathrm{kPa} \\
\text { - Rad. Collagen Stiffness: } 1.29 \pm 0.27 \mathrm{MPa}\end{array}$ & $\begin{array}{l}\text { Aortic valve tissue } \\
\text { engineering }\end{array}$ & [205] \\
\hline Decellularization & $\begin{array}{l}\text { Decellularized } \\
\text { collagen } \\
\text { or } \\
\text { Decellularized } \\
\text { elastin } \\
\text { from porcine } \\
\text { aorta } \\
\end{array}$ & $\begin{array}{l}\text { - Pore Size (elastin): } 10-40 \times 30-120 \mu \mathrm{m} \\
\text { - Pore Size (collagen): diameter }=3-20 \mu \mathrm{m} \\
\text { - Tensile Strength (elastin): } 269 \pm 9 \mathrm{kPa} \\
\text { - Tensile Strength (collagen): } 167 \pm 26 \mathrm{kPa} \\
\text { - Extensibility (elastin): } 1.08 \pm 0.02 \\
\text { - Extensibility (collagen): } 0.22 \pm 0.01\end{array}$ & $\begin{array}{c}\text { Cardiovascular Tissue } \\
\text { Engineering }\end{array}$ & [206] \\
\hline Decellularization & $\begin{array}{c}\text { Decellularized } \\
\text { whole rat } \\
\text { heart }\end{array}$ & $\begin{array}{l}\text { - Proteins Maintained: collagen I, collagen III, } \\
\text { laminin, fibronectin } \\
\text { - Decell Stiffness: } \sim 600 \mathrm{kPa} \\
\text { - Myofiber Size: } 250 \mu \mathrm{m}-1.1 \mathrm{~mm} \text { thick }\end{array}$ & $\begin{array}{l}\text { Whole heart tissue } \\
\text { engineering }\end{array}$ & [207] \\
\hline Decellularization & $\begin{array}{l}\text { Decellularized } \\
\text { porcine } \\
\text { omentum } \\
+ \\
\mathrm{Au} \\
\text { nanoparticles } \\
\end{array}$ & $\begin{array}{l}\text { - Fiber Diameter: } 100 \mathrm{~nm}->1 \mu \mathrm{m} \\
\text { - Au nanoparticle Size: } 4 \text { or } 10 \mathrm{~nm} \\
\text { - Scaffold Stiffness: } \sim 10-15 \mathrm{MPa}\end{array}$ & $\begin{array}{l}\text { Conductive cardiac patch } \\
\text { tissue engineering }\end{array}$ & [208] \\
\hline Decellularization & $\begin{array}{l}\text { Decellularized } \\
\text { human } \\
\text { pericardium }\end{array}$ & $\begin{array}{l}\text { - Non X-linked Compressive Strength: } 19.7 \pm \\
2.1 \mathrm{kPa} \\
\text { - X-linked Compressive Strength: } \\
33.7 \pm 4.3 \mathrm{kPa} \\
\text { - Pore Size: } 70 \pm 12 \mu \mathrm{m} \\
\text { - Porosity (percentage): } 98.2 \%\end{array}$ & $\begin{array}{l}\text { Cardiac patch tissue } \\
\text { engineering } \\
\text { (human sourced) }\end{array}$ & [209] \\
\hline Decellularization & $\begin{array}{c}\text { Decellularized } \\
\text { whole human } \\
\text { heart }\end{array}$ & $\begin{array}{l}\text { - Decell Mass: } 85 \% \text { of donor heart } \\
\text { - Structure: vasculature, chordae tendineae, } \\
\text { valve leaflets, papillary muscles, and } \\
\text { alignment of myocardial fibers maintained } \\
\text { - dP/dV Compliance: } 84 \% \text { after decell in LV } \\
\text { and } 27 \% \text { in RV }\end{array}$ & $\begin{array}{l}\text { Whole human heart cardiac } \\
\text { tissue engineering }\end{array}$ & {$[210]$} \\
\hline Electrospinning & $\begin{array}{c}\text { Poly(lactic-co- } \\
\text { glycolic) acid } \\
+ \\
\text { laminin } \\
\text { derived } \\
\text { peptides }\end{array}$ & $\begin{array}{l}\text { - Fiber Diameter: } \sim 412-1248 \mathrm{~nm} \text { dependent on } \\
\text { solution viscosity }(4-8 \mathrm{w} / \mathrm{v} \%) \\
\text { - Fiber Alignment: } 67.1 \% \text { fibers aligned within } \\
\pm 30 \text { degrees of axis of alignment } \\
\text { - Peptide Density: } 3.23 \pm 0.068 \mathrm{nmol} / \mathrm{cm}^{2} \\
\text { (normalized to fiber surface area) }\end{array}$ & $\begin{array}{l}\text { Cardiac patch tissue } \\
\text { engineering }\end{array}$ & [211] \\
\hline
\end{tabular}




\begin{tabular}{|c|c|c|c|c|}
\hline Electrospinning & $\begin{array}{l}\text { Poly(lactic-co- } \\
\text { glycolic) acid } \\
\quad \text { or } \\
\text { Polycarbonate } \\
\text {-urethane }\end{array}$ & $\begin{array}{l}\text { - Fiber Diameter (PLGA): } 280.4 \pm 96.5 \mathrm{~nm} \\
\text { - Fiber Diameter (PCU): } 699.4 \pm 201.1 \mathrm{~nm} \\
\text { - Stiffness (PLGA): } 50-300 \mathrm{MPa} \text { dependent } \\
\text { on target collected on } \\
\text { - Stiffness (PCU): } 0.5-2.0 \mathrm{MPa} \text { dependent on } \\
\text { target collected on }\end{array}$ & $\begin{array}{c}\text { Regenerative cardiac tissue } \\
\text { engineering }\end{array}$ & [212] \\
\hline Electrospinning & $\begin{array}{c}\text { Poly( }(\varepsilon- \\
\text { caprolactone) }\end{array}$ & $\begin{array}{l}\text { - Stiffness (straight fiber): } \sim 0.15 \mathrm{MPa} \\
\text { - Stiffness (spring fiber): } \sim 0.05 \mathrm{MPa} \\
\text { - Extensibility (straight fiber): } \sim 115 \% \\
\text { - Extensibility (spring fiber): } \sim 275 \% \\
\text { - Pore Area (straight fibers): } 1000 \mu \mathrm{m}^{2} \\
\text { - Pore Area (spring fibers): } 4000 \mu \mathrm{m}^{2} \text {, diameter } \\
\quad \sim 70 \mu \mathrm{m}\end{array}$ & $\begin{array}{l}\text { Cardiac patch tissue } \\
\text { engineering }\end{array}$ & [213] \\
\hline Electrospinning & $\begin{array}{l}\text { Poly(glycerol } \\
\text { sebacate) - } \\
\text { poly( }(\varepsilon- \\
\text { caprolactone) } \\
+ \\
\text { VEGF }\end{array}$ & $\begin{array}{l}\text { - Fiber diameter: } 0.8 \pm 0.3 \mu \mathrm{m} \\
\text { - Pore Size: } 2.2 \pm 1.2 \mu \mathrm{m} \\
\text { - Porosity (percentage non-scaffold): } 62 \pm 4 \% \\
\text { - Hydraulic Permeability: } 4 \times 10^{-6} \mathrm{~cm} /(\mathrm{sPa}) \\
\text { - Intrinsic Permeability: } 2 \times 10^{-3} \mathrm{Darcy} \\
\text { - Stiffness: } 8 \pm 2 \mathrm{MPa} \\
\text { - Ultimate Tensile Strength: } 3 \pm 0.5 \mathrm{MPa} \text { at } 142 \\
\pm 29 \% \text { strain } \\
\text { - Protein concentration: } 1.0 \mu \mathrm{g} / \mathrm{cm}^{2}\end{array}$ & $\begin{array}{l}\text { Cardiac patch tissue } \\
\text { engineering }\end{array}$ & [214] \\
\hline Electrospinning & $\begin{array}{l}\text { Poly(glycerol } \\
\text { sebacate) }- \\
\text { poly( } \varepsilon^{-} \\
\text {caprolactone) }\end{array}$ & $\begin{array}{l}\text { - Fiber Diameter: } \sim 3.5-10 \mu \mathrm{m} \text { dependent on } \\
\text { polymer ratios } \\
\text { - Pore Size: } \sim 40-5010 \mu \mathrm{m} \text { dependent on } \\
\text { polymer ratios } \\
\text { - Stiffness (parallel to fiber axis): } 4.16 \pm 1.0 \text { - } \\
9.28 \pm 0.43 \mathrm{MPa} \text { dependent on polymer ratios } \\
\text { - Stiffness (perpendicular to fiber axis): } 0.95 \pm \\
0.68-1.21 \pm 0.33 \mathrm{MPa} \text { dependent on polymer } \\
\text { ratios }\end{array}$ & $\begin{array}{c}\text { Cardiac valve tissue } \\
\text { engineering }\end{array}$ & [215] \\
\hline Electrospinning & $\begin{array}{l}\text { Poly(ester } \\
\text { urethane)urea }\end{array}$ & $\begin{array}{l}\text { - Fiber Alignment: }>0.6 \text { orientation index } \\
\text { - Ultimate Tensile Strength (circ): } 12.2 \text { - } \\
16.2 \mathrm{MPa} \text { dependent on collection technique } \\
\text { - Ultimate Tensile Strength (rad): } 3.3 \pm 1.3 \text { - } \\
6.4 \pm 1.1 \mathrm{MPa} \text { dependent on collection } \\
\text { technique } \\
\text { - Suture Retention Strength: } 64.9 \pm 6.2 \text { - } \\
102 \pm 8.4 \mathrm{~N} / \mathrm{mm}^{2} \text { dependent on collection } \\
\text { technique }\end{array}$ & $\begin{array}{c}\text { Pulmonary valve tissue } \\
\text { engineering }\end{array}$ & [216] \\
\hline Electrospinning & $\begin{array}{l}\text { Poly(ethylene } \\
\text { glycol) } \\
\text { dimethacrylate } \\
\text { - poly(l- } \\
\text { lactide) }\end{array}$ & $\begin{array}{l}\text { - Fiber Diameter: } 0.37 \pm 0.08 \mu \mathrm{m} \\
\text { - Stiffness: } 141 \pm 23.6 \mathrm{MPa} \\
\text { - Ultimate Tensile Strength: } 2.1 \pm 0.3 \mathrm{MPa} \\
\text { - Extensibility: } 4 \pm 0.4 \% \\
\text { - Pore Size: } 8.24 \pm 6.23 \mu \mathrm{m}^{2} \\
\text { - Swelling Ratio: } 59 \pm 6 \% \\
\text { - } \text { Contact Angle (water): } 38.7 \pm 10.9^{\circ} \\
\end{array}$ & $\begin{array}{l}\text { Cardiac valve tissue } \\
\text { engineering }\end{array}$ & [217] \\
\hline $\begin{array}{l}\text { Force Spinning } \\
\quad \text { (RJS) }\end{array}$ & $\begin{array}{l}\text { Poly(lactic } \\
\text { acid) } \\
\text { or } \\
\text { Gelatin }\end{array}$ & $\begin{array}{l}\text { - Fiber Diameter (PLA): } 424 \pm 41-1143 \pm \\
\text { 50nm dependent on fiber extrusion speed } \\
\text { - Fiber Diameter (gelatin): } 515 \pm 27 \mathrm{~nm}\end{array}$ & Cardiac tissue engineering & [28] \\
\hline $\begin{array}{l}\text { Force Spinning } \\
\text { (RJS) }\end{array}$ & $\begin{array}{c}\operatorname{poly}(\varepsilon- \\
\text { caprolactone }) \\
\text { - Gelatin }\end{array}$ & $\begin{array}{l}\text { - Fiber Diameter: } \sim 0.4-1.5 \mu \mathrm{m} \text { dependent on } \\
\text { polyer:protein ratio (increasing with } \\
\text { increasing protein content) } \\
\text { - Fiber Alignment: } \sim 0.9-0.5 \text { orientation order } \\
\text { parameter, dependent on polyer:protein ratio } \\
\text { (decreasing with increasing protein content) } \\
\text { - Stiffness (75/25 PCL/Gelatin): } \sim 15 \mathrm{MPa} \\
\text { - Stiffness (PCL): } \sim 300 \mathrm{MPa}\end{array}$ & $\begin{array}{l}\text { Cardiac Tissue } \\
\text { Engineering }\end{array}$ & [29] \\
\hline
\end{tabular}




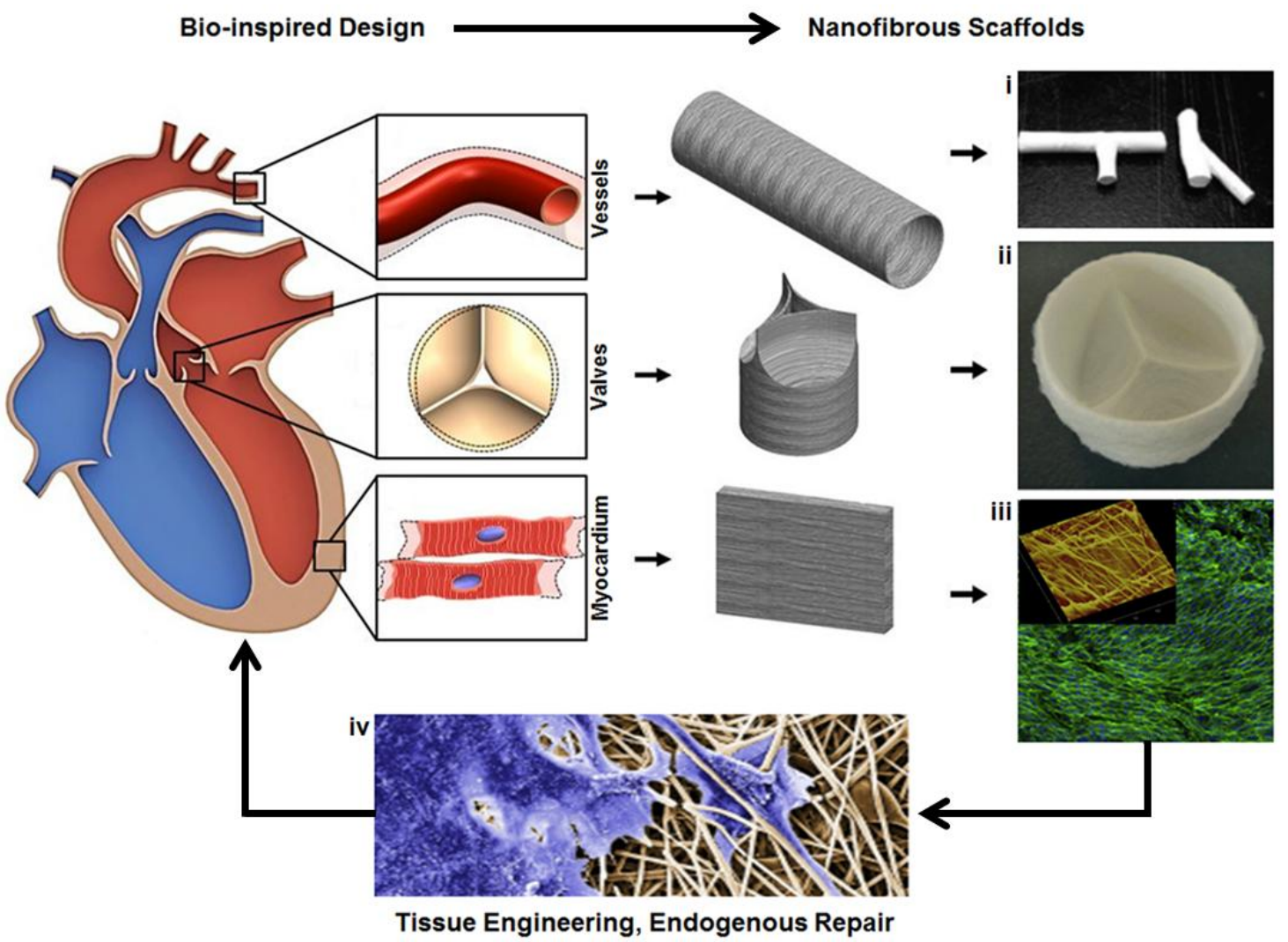

Fig. 6. Overview of bio-inspired fibrous scaffold fabrication for cardiac tissue engineering. Native cardiac tissue structure and function provide design criteria for engineered fibrous scaffolds. Synthetic vessel, valve, and myocardial scaffolds have each been produced: (i) Electrospun 3D nanofibrous tubes with controllable architectures. Reprinted from [218] with permission from American Chemical Society Publications. (ii) Electrospun trileaflet valve scaffold. Reprinted from [219] with permission from Elsevier; (iii)Confocal micrograph electrospun scaffolds seeded with $\mathrm{H} 9 \mathrm{C} 2$ cardiomyoblasts demonstrating cell alignment (Green: F-actin (phalloidin), blue: nuclei (DAPI)), inset shows an atomic force microscopic (AFM) image of the scaffold's 3D surface topography. Scanning area is 50 x $50 \mu \mathrm{m}$. Reprinted from [212] with permission from Elsevier; (iv) Valve interstitial cells infiltrating electrospun scaffolds (SEM colored). Reprinted from [217] with permission from Elsevier. 


\section{Cardiac Tissue Repair Using Fibrous Scaffolds}

The overall strategy for designing synthetic cardiac tissues using bio-inspired nanofibrous scaffolds is summarized in Fig. 6. Given the complexity involved in assessing the quality of traditional tissue engineered products that are seeded, cultured, and conditioned in vitro, how practical — logistically — is their translation to common usage in the clinic? There are currently no standardized guidelines for determining the fitness of engineered heart tissues, although attempts to use computer algorithms relying on gene expression profiles, structural phenotyping, and statistical combination of structural and functional measurements have been proposed to allow reliable, quantitative comparison [44-46, 220]. The appropriate cell sources at the necessary seeding densities must be identified, customized bioreactors built, optimization of conditioning parameters established, and standards for desired tissue growth established before implantation can be attempted. This level of in vitro customization results in high cost and time to clinic for a tissue engineered scaffold [220-222], limiting the success of the process and product. Traditional tissue engineered scaffolds that are seeded with cells in vitro are evaluated by a number of biological parameters such as how the cells adhere to and penetrate the scaffold, what and when phenotypic changes occur, the metabolic activity of the cells/tissue, and how the cells/tissue function in vitro [108]. How these parameters change over time depends on the scaffold, cells, culture conditions, bioreactors, and time in culture which are unique to each application and are likely to change dramatically post implant. By focusing on cell-free scaffolds, we can apply well defined quality metrics to the scaffold itself [223, 224]. Scaffold qualities that include mechanics, biochemical composition, porosity, fiber alignment, three dimensional architecture, and cargo release profiles can be precisely and quantitatively measured. Fabricating cell-free scaffolds from the ground up (i.e. using as few biochemical components as are necessary) not 
Capulli, MacQueen, et al. Fibrous Scaffolds for Building Hearts $\quad$ Last Edited: 11/12/2015

only provides precisely measurable quality control metrics but also simplifies the host-response problem by narrowing the parameter space.

\subsection{Heart Structure Following Injury or Disease}

Scaffolds designed for cardiac repair aim to improve upon the body's limited endogenous repair mechanisms. Heart failure is often associated with tissue fibrosis and scarring [34] and fibrosis throughout the cardiovascular system leads to maladaptive remodeling and inefficient function of myocardial, valve, and vascular tissues. Fibrosis in the myocardium due to infarct can cause hypertrophic expansion of the ventricles leading to poor contractile efficiency and reduced cardiac output. Fibrosis of the cardiac valves can lead to calcification, resulting in stenosis and/or insufficiency and reduced cardiac output. Repairing and preventing the structural remodeling resulting from these pathological conditions requires that synthetic scaffolds provide the biological cues necessary to direct cellular activity in a manner that inhibits or reverses scar formation.

Myofibroblasts are the primary ECM-secreting cells during wound healing and fibrosis [221]. The transition of fibroblasts to myofibroblasts is an early event in hypertensive heart disease and following myocardial infarction [34] that is regulated in part by mechanical tension and increased expression of renin-angiotensin-aldosterone (RAAS) hormones, endothelin-1, and transforming growth factor- $\beta 1$ (TGF- $\beta 1)$ [5, 222]. Altered balance of matrix metalloproteinases (MMP)s and their inhibitors (tissue inhibitor MMP, TIMP) can stiffen the ECM [34], which is known to alter myocyte shape and contractile function [8]. Post-injury remodeling of the myocardium is associated with disrupted excitation-contraction coupling [34] and increased risk 
for arrhythmogenesis [223]. Functional restoration of cardiac tissues therefore requires strategies that regulate these factors and produce outcomes that are superior to scarring.

\subsection{Fibrous Scaffolds for Myocardial Tissue Regeneration}

Fibrous scaffolds have been designed for myocardial tissue engineering and patching to restore partial contractile function to infarcted ventricular myocardium. Many of these approaches support the benefit of using ECM-inspired nanofibrous scaffolds to mimic native tissue anisotropy and thereby enhance cell assembly into functional contractile myocardial tissues. Utilization of ECM proteins that are typically found in the native tissue is postulated to serve as a promising strategy for designing fibrous scaffolds optimized for myocardial repair. For example, Serpooshan et al. [224] demonstrated that an engineered acellular scaffold comprising type I collagen grafted onto the infarcted myocardium in adult murine hearts immediately after ligation of left anterior descending artery significantly protected the cardiac tissue from injury at the anatomical and functional levels. Patched ventricles showed attenuated left ventricular remodeling, diminished fibrosis, and formation of a network of interconnected blood vessels within the infarct (Table 10). These studies provide strong evidence that acellular biomaterials with ECM-like properties can modulate endogenous repair mechanisms and attenuate pathological remodeling to improve heart function following myocardial infarction.

Further efforts attempted to combine the cell-instructive capabilities of natural ECM proteins with the enhanced structural stability of biodegradable polymers to form so-called "biohybrid" nanofibers. Electrospinning is the most widely used method for biohybrid cardiac patch production (Table 10) and several studies have demonstrated enhanced structure and function of engineered cardiac tissues by further doping the scaffold with electrically conductive materials 
[225, 226]. For example, Dvir et al. [225] observed improved contractile synchronicity in cardiac tissues that were grown in porous alginate scaffolds that contained gold nanowires compared to alginate scaffolds alone. More recently, Kharaziha et al. [226] reported stronger spontaneous and synchronous beating behavior (3.5-fold lower excitation threshold and 2.8-fold higher maximum capture rate) of cardiac tissues grown on aligned poly(-glycerol sebacate):gelatin (PG) electrospun nanofibrous scaffolds that contained carbon nanotubes compared to those cultured on PG scaffold alone. These studies provide a glimpse into the potential that nanofibrous scaffolds have to serve as substrates as bioactive myocardial patches.

The use of cells and bioactive molecules to target endogenous repair mechanisms for cardiac repair was recently reviewed by Hastings et al. [227]. They noted that acellular materialbased molecule delivery strategies do not require cell engraftment prior to implantation and can aid in clinical translation. They reviewed the potential to load small molecules such as prostaglandins and pyrvinium pamoate, RNA therapeutics, growth factors and proteins into biomaterial matrices provided that the release kinetics can be controlled. A variety of molecules have been successfully loaded into fiber scaffolds, including antibiotics and antibacterial agents, anticancer drugs, protein, DNA, RNA, and growth factors, and their release kinetics determined [228]. Drug release from electrospun fibers can be controlled by engineering nanofibers that undergo alterations in response to $\mathrm{pH}$, temperature, light, electric fields, or combined stimuli [229]. The incorporation of these components into nanofiber scaffolds enhances cardiac repair by mitigating host rejection and promoting successful engraftment. For example, controlled delivery of FGF1 and neuregulin-1 growth factors promoted cardiac repair in a rat myocardial infarction model [230] and an angiogenic factor, FGF2, combined with an anti-inflammatory cytokine, interleukin-10, synergistically enhanced ischemic heart repair [231]. The incorporation of anti- 
Capulli, MacQueen, et al. Fibrous Scaffolds for Building Hearts $\quad$ Last Edited: 11/12/2015

inflammatory agents is an important consideration in the design of biomaterial scaffolds for therapeutic applications, but determining the most effective method to release the most relevant combination of factors is a continuing challenge [232].

Although electrospinning is the most commonly used method for nanofiber production, force extrusion is emerging as an alternative with a number of production advantages, such as higher throughput. For example, Bursac et al. [233] created aligned 3D polymer scaffolds by casting poly(lactic-co-glycolic) acid (PLGA) on extrusion-spun fibrous sucrose templates. They used a cotton candy machine to extrude sucrose fibers that were then manually stretched and pressed to form thin sheets. The sucrose templates were coated with PLGA solutions and the sucrose was leached out leaving PLGA scaffolds that were coated with fibronectin to promote cell adhesion to the scaffolds. Neonatal rat cardiac cells cultured on these scaffolds aligned and interconnected to form multiple bundles that exhibited anisotropic electrophysiological properties. Conduction velocity anisotropy ratios of 2 obtained after 2 weeks of culture were in agreement with those previously measured in neonatal ventricles. Given these early demonstrations of successful cardiac patch production and appreciating that force-spinning is a rapidly evolving technology platform [28, 29, 200], we expect these methods will be increasingly applied to myocardial tissue engineering. 
Table 10. Effects of fibrous scaffolds used for cardiac tissue engineering

\begin{tabular}{|c|c|c|c|c|}
\hline Scaffold material & Key scaffold properties & Cell sources & Key experimental results & Ref. \\
\hline $\begin{array}{l}\text { Electrospun PLLA and } \\
\text { PLGA }\end{array}$ & $\begin{array}{l}\text { PLGA membranes were } \\
\text { uniaxially stretched to achieve } \\
\text { anisotropic fiber architectures }\end{array}$ & $\begin{array}{l}\text { NRCM isolated } \\
\text { from 2-4 day old } \\
\text { Sprague-Dawley } \\
\text { rats }\end{array}$ & $\begin{array}{l}\text { In vitro: Cardiomyocyte isotropic or anisotropic } \\
\text { growth controlled by fiber structural cues }\end{array}$ & [234] \\
\hline $\begin{array}{l}\text { Electrospun polyester } \\
\text { blend (PHBV }(5 \% \mathrm{HV}) \\
\text { P(L-D,L)LA }(70: 30) \text { and } \\
\text { PGS) }\end{array}$ & $\begin{array}{l}\text { Included biodegradable } \\
\text { macroporous tubes to perfuse } \\
\text { the scaffold }\end{array}$ & $\begin{array}{l}\text { hMSC from human } \\
\text { umbilical cord }\end{array}$ & $\begin{array}{l}\text { In vitro: Fibers aligned MSCs, perfusion of } \\
\text { medium through macroporous tubes increased } \\
\text { MSC viability }\end{array}$ & [235] \\
\hline $\begin{array}{l}\text { Electrospun } \\
\text { PCL/gelatin }\end{array}$ & $\begin{array}{l}\text { Biodegradable nanofibrous } \\
\text { cardiac patch. Nanofiber } \\
\text { diameter }=244 \pm 51 \mathrm{~nm}\end{array}$ & $\begin{array}{l}\text { MSC isolated from } \\
\text { rat bone marrow }\end{array}$ & $\begin{array}{l}\text { Rat Model: Patch reduced scar size and } \\
\text { increased vessel density in MI model. }\end{array}$ & [236] \\
\hline Electrospun PCL & Plasma surface functionalized & MSC & $\begin{array}{l}\text { Rat Model: Patch attenuated dilatation in MI } \\
\text { model. Ejection fraction decrease was } 6 \% \text { in } \\
\text { patched hearts vs } 13 \% \text { in sham }\end{array}$ & [237] \\
\hline $\begin{array}{l}\text { Electrospun } \\
\text { PLGA and thermoplastic } \\
\text { polycarbonate-urethane } \\
(\text { PCU, Bionate }())\end{array}$ & Textile-templated & $\begin{array}{l}\text { H9C2 rat cardiac } \\
\text { myoblast cell line, } \\
\text { NRCM isolated } \\
\text { from } 1-3 \text { day old } \\
\text { Sprague-Dawley } \\
\text { rats }\end{array}$ & $\begin{array}{l}\text { In vitro: Myocyte alignment, elongation, and } \\
\text { improved contractile synchrony on templated } \\
\text { scaffolds }\end{array}$ & [212] \\
\hline $\begin{array}{l}\text { Electrospun PGS/gelatin } \\
\text { with embedded carbon } \\
\text { nanotubes }(\mathrm{CNT})\end{array}$ & CNT: 0 to $1.5 \%$ & $\begin{array}{l}\text { NRCM isolated } \\
\text { from } 2 \text { day old } \\
\text { Sprague-Dawley } \\
\text { rats }\end{array}$ & $\begin{array}{l}\text { In vitro: CNT inclusion reduced excitation } \\
\text { threshold and increased maximum capture rate }\end{array}$ & [226] \\
\hline $\begin{array}{l}\text { Assembly of alginate }+ \\
\text { gold nanowires (NW) } \\
\text { composite }\end{array}$ & $\begin{array}{l}\text { Macroporous hydrogel, } \\
\text { Compressive moduli }(\mathrm{kPa}) \text { : } \\
\text { Alg: } 1.2 \pm 0.2 \\
\text { Alg+NW: } 3.5 \pm 0.2\end{array}$ & $\begin{array}{l}\text { NRCM (0-1 day } \\
\text { old) }\end{array}$ & $\begin{array}{l}\text { In vitro: Gold NW inclusion improved } \\
\text { engineered cardiac tissue contractile } \\
\text { synchronicity }\end{array}$ & [225] \\
\hline $\begin{array}{l}\text { PLGA hydrogel cast on } \\
\text { force-spun fibrous } \\
\text { sucrose templates }\end{array}$ & $\begin{array}{l}\text { PLGA solutions were cast on } \\
\text { extrusion-spun fibrous sucrose } \\
\text { templates. Sucrose was } \\
\text { subsequently leached. }\end{array}$ & $\begin{array}{l}\text { NRCM isolated } \\
\text { from 2-3 day old } \\
\text { Sprague-Dawley } \\
\text { rats }\end{array}$ & $\begin{array}{l}\text { In vitro: Anisotropic } \\
\text { cell alignment and electrical propagation. Two- } \\
\text { fold higher conduction velocity along vs. across } \\
\text { cardiac fibers }\end{array}$ & [233] \\
\hline $\begin{array}{l}\text { PGS hydrogel } \\
\text { synthesized by } \\
\text { polycondensation of } \\
\text { glycerol and sebacic } \\
\text { acid }\end{array}$ & $\begin{array}{l}\text { PGS materials synthesized at } \\
110,120 \text { and } 130{ }^{\circ} \mathrm{C} \text { had } \\
\text { Young's moduli of } 0.056,0.22 \\
\text { and } 1.2 \mathrm{MPa} \text {, respectively }\end{array}$ & Acellular & $\begin{array}{l}\text { In vitro: Demonstrated a range of controllable } \\
\text { stiffness and degradation kinetics }\end{array}$ & [238] \\
\hline $\begin{array}{l}\text { Commercial porous } \\
\text { collagen sponge } \\
\text { hydrogel }\end{array}$ & $\begin{array}{l}\text { Cytokine-conjugated system: } \\
\text { Covalently-immobilized } \\
\text { proangiogenic cytokines } \\
\text { (VEGF, bFGF) }\end{array}$ & $\begin{array}{l}\text { hMSC from young } \\
(50.0 \pm 8.0 \text { years, } \mathrm{N} \\
=4) \text { or old }(74.5 \pm \\
7.4 \text { years, } \mathrm{N}=4) \\
\text { donors }\end{array}$ & $\begin{array}{l}\text { In vitro: Enhanced cell proliferation } \\
\text { Rat Model: Prolonged cell survival and } \\
\text { improved angiogenesis following surgical } \\
\text { ventricular restoration. Ejection fraction } \\
\text { correlated with cell survival, patch thickness, } \\
\text { and vascular density }\end{array}$ & [239] \\
\hline $\begin{array}{l}\text { Compressed type I } \\
\text { collagen hydrogel }\end{array}$ & $\begin{array}{l}\text { Hydrogels were compressed to } \\
\text { achieve compressive modulus, } \\
\mathrm{E}_{\mathrm{c}} \sim 5 \mathrm{kPa}\end{array}$ & Acellular & $\begin{array}{l}\text { Rat Model: Attenuated left ventricular } \\
\text { remodeling, diminished fibrosis, and enhanced } \\
\text { blood vessel formation following myocardial } \\
\text { infarct }\end{array}$ & [224] \\
\hline \multicolumn{5}{|c|}{$\begin{array}{l}\text { Abbreviations: bFGF, basic fibroblast growth factor; CNT, carbon nanotubes; GAG, glycosoaminoglycan; MI, Myocardial infarction; MSC, } \\
\text { mesenchymal stem cell; hMSC, human mesenchymal stem cell; NRCM, neonatal rat cardiomyocyte; PCL, polycaprolactone; PGA, poly(glycolic } \\
\text { acid);PGS, poly(glycerol sebacate); PHBV, Poly(3-hydroxybutyrate-co-3-hydroxyvalerate); PLGA, poly(lactic-co-glycolic) acid; PLLA, poly(L- } \\
\text { lactic acid); POC, poly(1,8-octanediol-co-citric acid); VEGF, vascular endothelial growth factor }\end{array}$} \\
\hline
\end{tabular}




\subsection{Fibrous Scaffolds for Valve Replacement}

In contrast to mechanical or bioprosthetic heart valves, fibrous constructs preserve multiscale features of natural valves and possess the ability to promote endogenous remodeling. These 3D fibrous valve scaffolds support cell culture and matrix remodeling in response to physiologically-relevant flows and pressures when cultured in vitro [240] or in vivo [241]. Implantation of non-endothelialized heart valve constructs into non-human primates resulted in nearly confluent endothelialization after just 4 weeks in vivo [242], suggesting that endothelialization prior to implantation may not be necessary. This is important because reducing long-term in vitro culture and conditioning simplifies design and testing and reduces risk of infection. Engineered valve scaffolds that are either seeded with patient-derived stem cells or implanted cell-free may overcome the limitations of immunogenic rejection reported for xenogenic or allogenic transplants. Importantly, they are not dependent on the availability of healthy human donor tissue and may be tailored to patient-specific needs. This is especially true for cell-free scaffolds for which informed design, based on patient data, scaffold fabrication and implantation can be achieved in less than a day. It may also be possible to implant these scaffolds using minimally invasive procedures. For example, Weber et al. [240] confirmed that the structure of tissue engineered valves based on a synthetic biodegradable PGA/polyester composite matrix was not affected by crimping, suggesting the feasibility of stented, catheter implantation. Although further study is required to assess the long-term function of these scaffolds in vivo, mounting evidence suggests that cell-free or minimally tissue engineered personalized valve scaffolds can provide immediate functional restoration with the potential for in vivo remodeling and improved host integration. 


\section{Design Challenges and Future Directions}

We began this review with the question can we build a heart? In order to provide a frame of reference for defining the aspects of heart function and disease that are being addressed using tissue engineering. Model cardiac tissue components that recapitulate portions of cardiac tissue structure and function have been engineered for both in vitro and in vivo applications. The design and build of these tissues are guided by what we observe and measure in the native tissue which likewise provides functional quality standards for their evaluation. The challenge moving forward is to establish goal-directed production based on clearly defined design criteria and benchmarks for success. To accomplish this, we must further define and determine scaling of the minimal, essential structures and functions of the native heart that need to be recapitulated. Tables such as those reported here instruct us on how to build cardiac tissue components as well as how to evaluate whole-organ function but we lack the understanding on how to translate between the two. Further, it is necessary to develop quantitative metrics that allow robust measurement and comparison of the parameters that define heart function. Computational algorithms allow quantitative assessment of traditionally qualitative measurements of biological form and function, such as calculation of global sarcomere alignment [45] or nuclear eccentricity [220] from fluorescence micrographs. Machine learning and statistical approaches for integrating the values from a variety of biochemical, structural, and functional experimental measurements into a single quality assessment score will allow comprehensive and reliable determination of engineered tissue quality [44, 46, 108]. As our knowledge of cardiac physiology grows, it would be of great utility to tabulate these data into a unified, digital repository that can be used to take a systems biology approach to defining comprehensive, clinically-relevant criteria for guiding the design of engineered cardiac tissues. 
Despite advances in our knowledge of the structure and mechanics of the heart, and improvements in the materials and production methods used to manufacture synthetic scaffolds, post-implantation monitoring of scaffold remodeling and performance will be challenging. Assessment of cell infiltration, scaffold degradation, degree of vascularization and remodeling can be accomplished with histological analysis following explantation. However, this type of analysis often requires termination of the growing scaffold/tissue complex. Real-time, nondestructive imaging and functional analysis methodologies capable of assessing engineered tissue performance in situ are needed to reveal the true time-dependent nature of the remodeling. Clinical diagnostic tools such as magnetic resonance imaging techniques (MRI) [225], computerized tomography (CT) [226], fluorescence imaging techniques [227], and echo/Doppler techniques may be useful to track scaffold/tissue growth and integration. Furthermore, fibrous scaffolds manufactured with dopants like magnetic or conductive nanoparticles can potentially be instrumented within the scaffold fibers during fabrication allowing for external, nondestructive monitoring of scaffold/tissue performance.

The need for vascularization strategies in tissue engineering was recognized early on [243] and remains a key challenge in the field [244-246]. The initiation of healthy angiogenesis has been and continues to be a primary concern for any implanted scaffold, from amorphous hydrogels [247] to highly aligned fibrous scaffolds. If, during the remodeling of the scaffold, angiogenesis is not initiated, the thickness of the tissue formed will be restricted to the diffusion limit of oxygen and nutrients from the surrounding vasculature ( 200 $\mu \mathrm{m}$ thick) [245]. To overcome this, scaffolds such as those designed for cardiac or skeletal muscle that require substantial thickness will benefit from the inclusion of angiogenic growth factors or initiators such as vascular endothelial growth factor (VEGF) to promote endogenous vascularization [248- 
250]. However, thicker scaffolds will not only need to be chemically and biologically designed to initiate angiogenesis, but must also be physically designed to allow for vessel infiltration. The porosity of a fibrous scaffold is therefore a critical design parameter for supporting vascularization of engineered tissues. For thicker scaffolds designed for myocardial repair, high porosity will be crucial for long-term, full regeneration. However, for tissues such as cardiac valves that must remain thin to be optimally functional, a balance between porosity levels high enough for cell infiltration but low enough to prevent vascularization will need to be achieved.

A similar balance and tuning of scaffold biochemical and mechanical properties will likewise need to be achieved to initiate an ideal inflammatory host response that will eventually promote healthy tissue regeneration. Defining the "healthy" level of inflammation is non-trivial: what is the minimal response to initiate endogenous tissue regeneration within the scaffold but not scarring or complete rejection? During the inflammatory phase of healing, matrix metalloproteinase (MMP) activation produces ECM fragments with potent pro-inflammatory actions affecting fibroblasts, endothelial cells, and leukocytes [42]. A key aim for cardiac regeneration strategies is the identification of signaling pathways that can be used to manage post-infarction inflammation, prevent excessive matrix degradation and attenuate adverse remodeling that leads to scar formation [251]. To accomplish this, anti-inflammatory, biologically-derived polymers [252] and synthetic anti-inflammatory drugs [253] have been incorporated directly into fibrous scaffolds. However, increasing the complexity of fibrous scaffolds by including more components, dopants, and cargo, may increase the risk for chronic inflammation and rejection. For example, instrumenting dopants such as conductive nanoparticles or nanotubes may cause chronic inflammation or toxicity [254], likely dependent on where the scaffold is implanted. Controlling the inflammatory and angiogenic responses of 
the body are important design considerations of fibrous scaffolds moving forward and will require substantial investigation into the basic science of regenerative cellular processes. The advantage of using synthetically produced fibrous scaffolds compared to decellularized tissues is particularly evident here, as they are built from the bottom-up, adding only the components that are essential to a given application and can be thoroughly tested for their capacity to induce an immunological response.

In addition to these basic science 'design' challenges, the industrial manufacturability of fibrous tissue engineered products is an important, often overlooked consideration that continues to limit their translation to the clinic. Manufacturing scalability, storage, and shelf-life optimization, as well as, the establishment and implementation of quality control standards are hurdles for clinical translation and the development of reproducible in vitro assays. The importance of quality control and process validation, utilizing the scientific method to improve manufacturing process performance, was first proposed in the 1930s [255]. The implementation of statistics-based quality management practices over the decades since has led to substantial improvements in manufacturing efficiency and product quality in a wide range of manufacturing sectors because it provides insight about when a process is drifting out of control, a critical advantage over subjective, judgement-based assessment [256]. Statistical quality control inspection practices have been refined into a quality control paradigm commonly known as "Six Sigma" that has been successfully utilized to minimize the occurrence of product defects by holding process variation to one-sixth the difference between process mean and the upper/lower design specification limits [256]. Multi-parameter statistical quality assessment strategies for stem cell manufacturing $[45,46]$ have already been implemented as well. We suggest the same can be done for fibrous tissue engineered products. Quantitative determination of standardized 
values for parameters such as fiber diameter, thickness, pore size, stiffness, and permeability similar to what is seen in decellularized ECM matrices (Table 9) will facilitate manufacturing and allow for standardized comparison. The adoption of these practices and standards will also accelerate products through the regulatory pathway if they are implemented early on in the development process. The translation of fibrous scaffolds into products with real patient impact will require a fusion of basic science and industrial manufacturing principles incorporated into the engineering design process.

\section{Conclusion}

In this review, we address the question, can we build a heart? Currently, mechanical ventricular assists and electronic pacemakers are able to restore the basic pumping functionality of the heart, and mechanical or fixed tissue valves can restore one-way flow functionality to damaged cardiac valves. However, prosthetic devices are only capable of sustaining basic function, and are not able to respond to dynamic changes in physiological demand. The heart is a living organ, capable of adapting its functional performance according to changing demands. By recapitulating the structure of the native heart using fibrous ECM scaffolds, it may be possible to build engineered heart tissues from cells that self-organize according to the guidance cues provided by the ECM into constructs capable of the physiological profile of native heart tissues. Despite current limitations, we have begun to define the multi-scale, developmental, structural, and functional design criteria necessary to faithfully recapitulate the essential components of a working heart. Methods for mimicking the fibrous ECM of the myocardium, such as decellularized tissue, electrospinning, and force spinning, provide the manufacturing methods and materials to build heart parts with relevant compositions and architectures for both in vitro 
and in vivo applications. In vitro platforms based on engineered cardiac tissues will increasingly be used to discover therapeutics and tandem approaches to implantable devices will facilitate host integration. However, incorporating bioactive components within scaffolds to enhance their cell-instructive capabilities presents new challenges for safety and efficacy regulation when therapeutic applications are considered. Diverse roles played by the ECM in regulating thrombosis, inflammation, angiogenesis, and mediating interaction between multiple cell types are largely unexplored in these systems. Although valve replacement with fibrous scaffolds may be achieved in the short term, the use of these scaffolds for myocardial repair requires further study in vitro and in vivo. Further elucidation of the interactions between myocardial cells and bioartificial scaffolds will allow the fabrication of myocardial tissue models that can be more successfully applied to basic cardiology, and drug discovery. Although routine clinical use of engineered scaffolds for cardiac tissue repair has yet to be achieved, our ability to re-create the heart from engineered component parts is continually advancing.

\section{Acknowledgments}

This work was funded by the John A. Paulson Harvard School of Engineering and Applied Sciences, the Wyss Institute for Biologically Inspired Engineering, the Harvard Materials Research Science and Engineering Center grant DMR-1420570, the National Center for Advancing Translational Sciences grant UH3 TR000522 "Human Cardio-Pulmonary System on a Chip," National Heart Lung and Blood Institute grant U01 HL100408 "Human Pluripotent Stem Cells and Progenitor Models of Cardiac and Blood Diseases," Defense Advanced Research Project Agency grant DARPA-BAA-11-73, and Defense Threat Reduction Agency grant DEAC52-06NA25396. This work was performed in part at the Center for Nanoscale Systems 
Capulli, MacQueen, et al. Fibrous Scaffolds for Building Hearts $\quad$ Last Edited: 11/12/2015

(CNS), a member of the National Nanotechnology Infrastructure Network (NNIN), which is supported by the National Science Foundation under NSF award no. ECS-0335765. CNS is part of Harvard University. 


\section{References}

[1] L.L. Hench, J.M. Polak, Third-generation biomedical materials, Science, 295 (2002) 1014-1017. [2] B.E. Dabiri, H. Lee, K.K. Parker, A potential role for integrin signaling in mechanoelectrical feedback, Progress in biophysics and molecular biology, 110 (2012) 196-203.

[3] N.G. Frangogiannis, Matricellular proteins in cardiac adaptation and disease, Physiological reviews, 92 (2012) 635-688.

[4] P. Bornstein, E.H. Sage, Matricellular proteins: extracellular modulators of cell function, Current opinion in cell biology, 14 (2002) 608-616.

[5] M. Dobaczewski, C. Gonzalez-Quesada, N.G. Frangogiannis, The extracellular matrix as a modulator of the inflammatory and reparative response following myocardial infarction, J Mol Cell Cardiol, 48 (2010) 504-511.

[6] J.H. Chen, C.A. Simmons, Cell-matrix interactions in the pathobiology of calcific aortic valve disease: critical roles for matricellular, matricrine, and matrix mechanics cues, Circ Res, 108 (2011) 1510-1524. [7] K.K. Parker, D.E. Ingber, Extracellular matrix, mechanotransduction and structural hierarchies in heart tissue engineering, Philosophical transactions of the Royal Society of London. Series B, Biological sciences, 362 (2007) 1267-1279.

[8] M.L. McCain, H. Yuan, F.S. Pasqualini, P.H. Campbell, K.K. Parker, Matrix elasticity regulates the optimal cardiac myocyte shape for contractility, American journal of physiology. Heart and circulatory physiology, 306 (2014) H1525-1539.

[9] A. Grosberg, P.W. Alford, M.L. McCain, K.K. Parker, Ensembles of engineered cardiac tissues for physiological and pharmacological study: heart on a chip, Lab Chip, 11 (2011) 4165-4173.

[10] A.W. Feinberg, P.W. Alford, H. Jin, C.M. Ripplinger, A.A. Werdich, S.P. Sheehy, A. Grosberg, K.K. Parker, Controlling the contractile strength of engineered cardiac muscle by hierarchal tissue architecture, Biomaterials, 33 (2012) 5732-5741.

[11] S.P. Sheehy, A. Grosberg, K.K. Parker, The contribution of cellular mechanotransduction to cardiomyocyte form and function, Biomech Model Mechanobiol, 11 (2012) 1227-1239.

[12] R.G. Harrison, The reaction of embryonic cells to solid structures, J Exp Zool, 17 (1914) 521-544.

[13] P. Weiss, Experiments on cell and axon orientation in vitro; the role of colloidal exudates in tissue organization, J Exp Zool, 100 (1945) 353-386.

[14] G.A. Dunn, T. Ebendal, Contact guidance on oriented collagen gels, Experimental cell research, 111 (1978) 475-479.

[15] A. Curtis, C. Wilkinson, Topographical control of cells, Biomaterials, 18 (1997) 1573-1583.

[16] N. Wang, J.P. Butler, D.E. Ingber, Mechanotransduction across the Cell-Surface and through the Cytoskeleton, Science, 260 (1993) 1124-1127.

[17] B.M. Gumbiner, Cell adhesion: the molecular basis of tissue architecture and morphogenesis, Cell, 84 (1996) 345-357.

[18] D.E. Ingber, Mechanosensation through integrins: Cells act locally but think globally, Proceedings of the National Academy of Sciences of the United States of America, 100 (2003) 1472-1474.

[19] B. Geiger, J.P. Spatz, A.D. Bershadsky, Environmental sensing through focal adhesions, Nat Rev

Mol Cell Bio, 10 (2009) 21-33.

[20] F.T. Bosman, I. Stamenkovic, Functional structure and composition of the extracellular matrix, The Journal of pathology, 200 (2003) 423-428.

[21] K.Y. Tsang, M.C. Cheung, D. Chan, K.S. Cheah, The developmental roles of the extracellular matrix: beyond structure to regulation, Cell and tissue research, 339 (2010) 93-110.

[22] B.S. Kim, D.J. Mooney, Development of biocompatible synthetic extracellular matrices for tissue engineering, Trends in biotechnology, 16 (1998) 224-230.

[23] P.X. Ma, Biomimetic materials for tissue engineering, Advanced drug delivery reviews, 60 (2008) 184-198.

[24] T. Dvir, B.P. Timko, D.S. Kohane, R. Langer, Nanotechnological strategies for engineering complex tissues, Nat Nanotechnol, 6 (2011) 13-22. 
[25] W.E. Teo, R. Inai, S. Ramakrishna, Technological advances in electrospinning of nanofibers, Sci Technol Adv Mat, 12 (2011).

[26] W.E. Teo, S. Ramakrishna, A review on electrospinning design and nanofibre assemblies, Nanotechnology, 17 (2006) R89-R106.

[27] Q.P. Pham, U. Sharma, A.G. Mikos, Electrospinning of polymeric nanofibers for tissue engineering applications: a review, Tissue engineering, 12 (2006) 1197-1211.

[28] M.R. Badrossamay, H.A. McIlwee, J.A. Goss, K.K. Parker, Nanofiber assembly by rotary jetspinning, Nano letters, 10 (2010) 2257-2261.

[29] M.R. Badrossamay, K. Balachandran, A.K. Capulli, H.M. Golecki, A. Agarwal, J.A. Goss, H. Kim, K. Shin, K.K. Parker, Engineering hybrid polymer-protein super-aligned nanofibers via rotary jet spinning, Biomaterials, 35 (2014) 3188-3197.

[30] P.A. Madurantakam, C.P. Cost, D.G. Simpson, G.L. Bowlin, Science of nanofibrous scaffold fabrication: strategies for next generation tissue-engineering scaffolds, Nanomedicine (Lond), 4 (2009) 193-206.

[31] C.V. Bouten, P.Y. Dankers, A. Driessen-Mol, S. Pedron, A.M. Brizard, F.P. Baaijens, Substrates for cardiovascular tissue engineering, Advanced drug delivery reviews, 63 (2011) 221-241.

[32] M.A. Laflamme, C.E. Murry, Heart regeneration, Nature, 473 (2011) 326-335.

[33] N.G. Frangogiannis, C.W. Smith, M.L. Entman, The inflammatory response in myocardial infarction, Cardiovascular research, 53 (2002) 31-47.

[34] B.C. Berk, K. Fujiwara, S. Lehoux, ECM remodeling in hypertensive heart disease, J Clin Invest, 117 (2007) 568-575.

[35] C.B. Patel, J.A. Cowger, A. Zuckermann, A contemporary review of mechanical circulatory support, The Journal of heart and lung transplantation : the official publication of the International Society for Heart Transplantation, 33 (2014) 667-674.

[36] G. Wang, M.L. McCain, L. Yang, A. He, F.S. Pasqualini, A. Agarwal, H. Yuan, D. Jiang, D. Zhang, L. Zangi, J. Geva, A.E. Roberts, Q. Ma, J. Ding, J. Chen, D.Z. Wang, K. Li, J. Wang, R.J. Wanders, W.

Kulik, F.M. Vaz, M.A. Laflamme, C.E. Murry, K.R. Chien, R.I. Kelley, G.M. Church, K.K. Parker, W.T. $\mathrm{Pu}$, Modeling the mitochondrial cardiomyopathy of Barth syndrome with induced pluripotent stem cell and heart-on-chip technologies, Nature medicine, 20 (2014) 616-623.

[37] K.H. Benam, S. Dauth, B. Hassell, A. Herland, A. Jain, K.J. Jang, K. Karalis, H.J. Kim, L.

MacQueen, R. Mahmoodian, S. Musah, Y.S. Torisawa, A.D. van der Meer, R. Villenave, M. Yadid, K.K. Parker, D.E. Ingber, Engineered in vitro disease models, Annual review of pathology, 10 (2015) 195-262. [38] A.P. Beltrami, L. Barlucchi, D. Torella, M. Baker, F. Limana, S. Chimenti, H. Kasahara, M. Rota, E. Musso, K. Urbanek, A. Leri, J. Kajstura, B. Nadal-Ginard, P. Anversa, Adult cardiac stem cells are multipotent and support myocardial regeneration, Cell, 114 (2003) 763-776.

[39] P.C.H. Hsieh, V.F.M. Segers, M.E. Davis, C. MacGillivray, J. Gannon, J.D. Molkentin, J. Robbins, R.T. Lee, Evidence from a genetic fate-mapping study that stem cells refresh adult mammalian cardiomyocytes after injury, Nature medicine, 13 (2007) 970-974.

[40] K.U. Hong, R. Bolli, Cardiac stem cell therapy for cardiac repair, Current treatment options in cardiovascular medicine, 16 (2014) 324.

[41] A. Behfar, R. Crespo-Diaz, A. Terzic, B.J. Gersh, Cell therapy for cardiac repair--lessons from clinical trials, Nature reviews. Cardiology, 11 (2014) 232-246.

[42] N.G. Frangogiannis, Regulation of the inflammatory response in cardiac repair, Circ Res, 110 (2012) 159-173.

[43] A.F. Bayomy, M. Bauer, Y.L. Qiu, R.L. Liao, Regeneration in heart disease-Is ECM the key?, Life sciences, 91 (2012) 823-827.

[44] P. Cahan, H. Li, S.A. Morris, E. Lummertz da Rocha, G.Q. Daley, J.J. Collins, CellNet: network biology applied to stem cell engineering, Cell, 158 (2014) 903-915.

[45] F.S. Pasqualini, S.P. Sheehy, A. Agarwal, Y. Aratyn-Schaus, K.K. Parker, Structural Phenotyping of Stem Cell-Derived Cardiomyocytes, Stem cell reports, 4 (2015) 340-347. 
[46] S.P. Sheehy, F. Pasqualini, A. Grosberg, S.J. Park, Y. Aratyn-Schaus, K.K. Parker, Quality Metrics for Stem Cell-Derived Cardiac Myocytes, Stem cell reports, 2 (2014) 282-294.

[47] M.J. Kocica, A.F. Corno, F. Carreras-Costa, M. Ballester-Rodes, M.C. Moghbel, C.N. Cueva, V. Lackovic, V.I. Kanjuh, F. Torrent-Guasp, The helical ventricular myocardial band: global, threedimensional, functional architecture of the ventricular myocardium, European journal of cardio-thoracic surgery : official journal of the European Association for Cardio-thoracic Surgery, 29 Suppl 1 (2006) S21-40.

[48] S. Fleischer, T. Dvir, Tissue engineering on the nanoscale: lessons from the heart, Curr Opin Biotech, 24 (2013) 664-671.

[49] T.F. Robinson, M.A. Geraci, E.H. Sonnenblick, S.M. Factor, Coiled perimysial fibers of papillary muscle in rat heart: morphology, distribution, and changes in configuration, Circ Res, 63 (1988) 577-592. [50] A.J. Pope, G.B. Sands, B.H. Smaill, I.J. LeGrice, Three-dimensional transmural organization of perimysial collagen in the heart, American journal of physiology. Heart and circulatory physiology, 295 (2008) H1243-H1252.

[51] P. Savadjiev, G.J. Strijkers, A.J. Bakermans, E. Piuze, S.W. Zucker, K. Siddiqi, Heart wall myofibers are arranged in minimal surfaces to optimize organ function, Proceedings of the National Academy of Sciences of the United States of America, 109 (2012) 9248-9253.

[52] T. Mammoto, A. Mammoto, D.E. Ingber, Mechanobiology and developmental control, Annu Rev Cell Dev Biol, 29 (2013) 27-61.

[53] S.P. Sheehy, K.K. Parker, The Role of Mechanical Forces in Guiding Tissue Differentiation, Stem Cells Biol Reg, (2011) 77-97.

[54] D.E. Ingber, N. Wang, D. Stamenovic, Tensegrity, cellular biophysics, and the mechanics of living systems, Rep Prog Phys, 77 (2014) 046603.

[55] A. Grosberg, P.L. Kuo, C.L. Guo, N.A. Geisse, M.A. Bray, W.J. Adams, S.P. Sheehy, K.K. Parker, Self-organization of muscle cell structure and function, PLoS Comput Biol, 7 (2011) e1001088.

[56] N.A. Geisse, S.P. Sheehy, K.K. Parker, Control of myocyte remodeling in vitro with engineered substrates, In Vitro Cell Dev Biol Anim, 45 (2009) 343-350.

[57] P.L. Kuo, H. Lee, M.A. Bray, N.A. Geisse, Y.T. Huang, W.J. Adams, S.P. Sheehy, K.K. Parker, Myocyte shape regulates lateral registry of sarcomeres and contractility, The American journal of pathology, 181 (2012) 2030-2037.

[58] A.M. Samarel, Costameres, focal adhesions, and cardiomyocyte mechanotransduction, American journal of physiology. Heart and circulatory physiology, 289 (2005) H2291-2301.

[59] V. Sequeira, L.L. Nijenkamp, J.A. Regan, J. van der Velden, The physiological role of cardiac cytoskeleton and its alterations in heart failure, Biochimica et biophysica acta, 1838 (2014) 700-722.

[60] P.A. Harvey, L.A. Leinwand, Cellular mechanisms of cardiomyopathy, Journal of Cell Biology, 194 (2011) 355-365.

[61] M.L. McCain, K.K. Parker, Mechanotransduction: the role of mechanical stress, myocyte shape, and cytoskeletal architecture on cardiac function, Pflugers Archiv : European journal of physiology, 462 (2011) 89-104.

[62] S. Huang, D.E. Ingber, Shape-dependent control of cell growth, differentiation, and apoptosis: switching between attractors in cell regulatory networks, Experimental cell research, 261 (2000) 91-103. [63] B.A. Danowski, K. Imanaka-Yoshida, J.M. Sanger, J.W. Sanger, Costameres are sites of force transmission to the substratum in adult rat cardiomyocytes, The Journal of cell biology, 118 (1992) 14111420.

[64] M. Hoshijima, Mechanical stress-strain sensors embedded in cardiac cytoskeleton: $Z$ disk, titin, and associated structures, American journal of physiology. Heart and circulatory physiology, 290 (2006) H1313-1325.

[65] B. Russell, M.W. Curtis, Y.E. Koshman, A.M. Samarel, Mechanical stress-induced sarcomere assembly for cardiac muscle growth in length and width, J Mol Cell Cardiol, 48 (2010) 817-823. 
[66] M.L. McCain, H. Lee, Y. Aratyn-Schaus, A.G. Kleber, K.K. Parker, Cooperative coupling of cellmatrix and cell-cell adhesions in cardiac muscle, Proceedings of the National Academy of Sciences of the United States of America, 109 (2012) 9881-9886.

[67] H. Lee, W.J. Adams, P.W. Alford, M.L. McCain, A.W. Feinberg, S.P. Sheehy, J.A. Goss, K.K. Parker, Cytoskeletal prestress regulates nuclear shape and stiffness in cardiac myocytes, Exp Biol Med (Maywood), (2015).

[68] S.P. Sheehy, S. Huang, K.K. Parker, Time-warped comparison of gene expression in adaptive and maladaptive cardiac hypertrophy, Circ Cardiovasc Genet, 2 (2009) 116-124.

[69] M.L. Decker, D.G. Simpson, M. Behnke, M.G. Cook, R.S. Decker, Morphological analysis of contracting and quiescent adult rabbit cardiac myocytes in long-term culture, Anat Rec, 227 (1990) 285299.

[70] S. Majkut, T. Idema, J. Swift, C. Krieger, A. Liu, D.E. Discher, Heart-specific stiffening in early embryos parallels matrix and myosin expression to optimize beating, Curr Biol, 23 (2013) 2434-2439.

[71] V.M. Christoffels, W.T. Pu, Developing insights into cardiac regeneration, Development, 140 (2013) 3933-3937.

[72] O. Bergmann, R.D. Bhardwaj, S. Bernard, S. Zdunek, F. Barnabe-Heider, S. Walsh, J. Zupicich, K. Alkass, B.A. Buchholz, H. Druid, S. Jovinge, J. Frisen, Evidence for Cardiomyocyte Renewal in Humans, Science, 324 (2009) 98-102.

[73] M. Mollova, K. Bersell, S. Walsh, J. Savla, L.T. Das, S.Y. Park, L.E. Silberstein, C.G. dos Remedios, D. Graham, S. Colan, B. Kuhn, Cardiomyocyte proliferation contributes to heart growth in young humans, Proceedings of the National Academy of Sciences of the United States of America, 110 (2013) 1446-1451.

[74] S.A. Muralidhar, A.I. Mahmoud, D. Canseco, F. Xiao, H.A. Sadek, Harnessing the power of dividing cardiomyocytes, Global cardiology science \& practice, 2013 (2013) 212-221.

[75] J.E. Hall, Guyton and Hall textbook of medical physiology, 13th edition. ed., Elsevier, Philadelphia, PA, 2016.

[76] M.R. Rosen, P.R. Brink, I.S. Cohen, R.B. Robinson, Cardiac pacing: from biological to electronic ... to biological?, Circulation. Arrhythmia and electrophysiology, 1 (2008) 54-61.

[77] M.R. Rosen, R.B. Robinson, P.R. Brink, I.S. Cohen, The road to biological pacing, Nature reviews. Cardiology, 8 (2011) 656-666.

[78] Y.F. Hu, J.F. Dawkins, H.C. Cho, E. Marban, E. Cingolani, Biological pacemaker created by minimally invasive somatic reprogramming in pigs with complete heart block, Science translational medicine, 6 (2014) $245 \mathrm{ra} 294$.

[79] S. Chauveau, P.R. Brink, I.S. Cohen, Stem cell-based biological pacemakers from proof of principle to therapy: a review, Cytotherapy, 16 (2014) 873-880.

[80] A.B. Arrenberg, D.Y. Stainier, H. Baier, J. Huisken, Optogenetic control of cardiac function, Science, 330 (2010) 971-974.

[81] T. Bruegmann, D. Malan, M. Hesse, T. Beiert, C.J. Fuegemann, B.K. Fleischmann, P. Sasse, Optogenetic control of heart muscle in vitro and in vivo, Nature methods, 7 (2010) 897-900.

[82] B.O. Bingen, M.C. Engels, M.J. Schalij, W. Jangsangthong, Z. Neshati, I. Feola, D.L. Ypey, S.F. Askar, A.V. Panfilov, D.A. Pijnappels, A.A. de Vries, Light-induced termination of spiral wave arrhythmias by optogenetic engineering of atrial cardiomyocytes, Cardiovascular research, 104 (2014) 194-205.

[83] C.M. Ambrosi, A. Klimas, J. Yu, E. Entcheva, Cardiac applications of optogenetics, Progress in biophysics and molecular biology, 115 (2014) 294-304.

[84] A.G. Kleber, Y. Rudy, Basic mechanisms of cardiac impulse propagation and associated arrhythmias, Physiological reviews, 84 (2004) 431-488.

[85] A.V. Glukhov, V.V. Fedorov, P.W. Kalish, V.K. Ravikumar, Q. Lou, D. Janks, R.B. Schuessler, N. Moazami, I.R. Efimov, Conduction remodeling in human end-stage nonischemic left ventricular cardiomyopathy, Circulation, 125 (2012) 1835-1847. 
[86] B.J. Caldwell, M.L. Trew, G.B. Sands, D.A. Hooks, I.J. LeGrice, B.H. Smaill, Three distinct directions of intramural activation reveal nonuniform side-to-side electrical coupling of ventricular myocytes, Circulation. Arrhythmia and electrophysiology, 2 (2009) 433-440.

[87] D.A. Hooks, K.A. Tomlinson, S.G. Marsden, I.J. LeGrice, B.H. Smaill, A.J. Pullan, P.J. Hunter, Cardiac microstructure: implications for electrical propagation and defibrillation in the heart, Circ Res, 91 (2002) 331-338.

[88] A.M. Katz, Ernest Henry Starling, his predecessors, and the "Law of the Heart", Circulation, 106 (2002) 2986-2992.

[89] H.L. Granzier, T.C. Irving, Passive tension in cardiac muscle: contribution of collagen, titin, microtubules, and intermediate filaments, Biophysical journal, 68 (1995) 1027-1044.

[90] H.L. Granzier, S. Labeit, The giant protein titin: a major player in myocardial mechanics, signaling, and disease, Circ Res, 94 (2004) 284-295.

[91] T.C. Irving, J. Konhilas, D. Perry, R. Fischetti, P.P. De Tombe, Myofilament lattice spacing as a function of sarcomere length in isolated rat myocardium, Am J Physiol-Heart C, 279 (2000) H2568$\mathrm{H} 2573$.

[92] L.M. Hanft, K.S. McDonald, Sarcomere length dependence of power output is increased after PKA treatment in rat cardiac myocytes, Am J Physiol-Heart C, 296 (2009) H1524-H1531.

[93] K.S. McDonald, The interdependence of $\mathrm{Ca} 2+$ activation, sarcomere length, and power output in the heart, Pflugers Archiv : European journal of physiology, 462 (2011) 61-67.

[94] Y. Ait Mou, J.Y. le Guennec, E. Mosca, P.P. de Tombe, O. Cazorla, Differential contribution of cardiac sarcomeric proteins in the myofibrillar force response to stretch, Pflugers Archiv : European journal of physiology, 457 (2008) 25-36.

[95] P.P. de Tombe, R.D. Mateja, K. Tachampa, Y. Ait Mou, G.P. Farman, T.C. Irving, Myofilament length dependent activation, J Mol Cell Cardiol, 48 (2010) 851-858.

[96] H.A. Shiels, E. White, The Frank-Starling mechanism in vertebrate cardiac myocytes, J Exp Biol, 211 (2008) 2005-2013.

[97] G. Iribe, M. Helmes, P. Kohl, Force-length relations in isolated intact cardiomyocytes subjected to dynamic changes in mechanical load, American journal of physiology. Heart and circulatory physiology, 292 (2007) H1487-1497.

[98] C. Bollensdorff, O. Lookin, P. Kohl, Assessment of contractility in intact ventricular cardiomyocytes using the dimensionless 'Frank-Starling Gain' index, Pflugers Archiv : European journal of physiology, 462 (2011) 39-48.

[99] M. Methawasin, K.R. Hutchinson, E.J. Lee, J.E. Smith, 3rd, C. Saripalli, C.G. Hidalgo, C.A. Ottenheijm, H. Granzier, Experimentally increasing titin compliance in a novel mouse model attenuates the Frank-Starling mechanism but has a beneficial effect on diastole, Circulation, 129 (2014) 1924-1936. [100] R. Wilders, Arrhythmogenic right ventricular cardiomyopathy: considerations from in silico experiments, Front Physiol, 3 (2012) 168.

[101] M.L. McCain, T. Desplantez, N.A. Geisse, B. Rothen-Rutishauser, H. Oberer, K.K. Parker, A.G. Kleber, Cell-to-cell coupling in engineered pairs of rat ventricular cardiomyocytes: relation between $\mathrm{Cx} 43$ immunofluorescence and intercellular electrical conductance, American journal of physiology. Heart and circulatory physiology, 302 (2012) H443-450.

[102] D. Burkhoff, I. Mirsky, H. Suga, Assessment of systolic and diastolic ventricular properties via pressure-volume analysis: a guide for clinical, translational, and basic researchers, American journal of physiology. Heart and circulatory physiology, 289 (2005) H501-512.

[103] A. Kolipaka, P.A. Araoz, K.P. Mcgee, A. Manduca, R.L. Ehman, Magnetic Resonance

Elastography as a Method for the Assessment of Effective Myocardial Stiffness Throughout the Cardiac Cycle, Magnetic resonance in medicine, 64 (2010) 862-870.

[104] C.H. Chen, B. Fetics, E. Nevo, C.E. Rochitte, K.R. Chiou, P.A. Ding, M. Kawaguchi, D.A. Kass, Noninvasive single-beat determination of left ventricular end-systolic elastance in humans, Journal of the American College of Cardiology, 38 (2001) 2028-2034. 
[105] E. Gayat, V. Mor-Avi, L. Weinert, C. Yodwut, R.M. Lang, Noninvasive quantification of left ventricular elastance and ventricular-arterial coupling using three-dimensional echocardiography and arterial tonometry, American journal of physiology. Heart and circulatory physiology, 301 (2011) H19161923.

[106] R.R. Chaturvedi, T. Herron, R. Simmons, D. Shore, P. Kumar, B. Sethia, F. Chua, E. Vassiliadis, J.C. Kentish, Passive stiffness of myocardium from congenital heart disease and implications for diastole, Circulation, 121 (2010) 979-988.

[107] K.W. Zhang, B. French, A. May Khan, T. Plappert, J.C. Fang, N.K. Sweitzer, B.A. Borlaug, J.A. Chirinos, M. St John Sutton, T.P. Cappola, B. Ky, Strain improves risk prediction beyond ejection fraction in chronic systolic heart failure, Journal of the American Heart Association, 3 (2014) e000550. [108] X. Yang, L. Pabon, C.E. Murry, Engineering adolescence: maturation of human pluripotent stem cell-derived cardiomyocytes, Circ Res, 114 (2014) 511-523.

[109] I.C. Turnbull, I. Karakikes, G.W. Serrao, P. Backeris, J.J. Lee, C. Xie, G. Senyei, R.E. Gordon, R.A. Li, F.G. Akar, R.J. Hajjar, J.S. Hulot, K.D. Costa, Advancing functional engineered cardiac tissues toward a preclinical model of human myocardium, Faseb J, 28 (2014) 644-654.

[110] E.I. Rossman, R.E. Petre, K.W. Chaudhary, V. Piacentino, 3rd, P.M. Janssen, J.P. Gaughan, S.R. Houser, K.B. Margulies, Abnormal frequency-dependent responses represent the pathophysiologic signature of contractile failure in human myocardium, J Mol Cell Cardiol, 36 (2004) 33-42.

[111] S.D. Lundy, W.Z. Zhu, M. Regnier, M.A. Laflamme, Structural and functional maturation of cardiomyocytes derived from human pluripotent stem cells, Stem Cells Dev, 22 (2013) 1991-2002. [112] E. Drouin, F. Charpentier, C. Gauthier, K. Laurent, H. Le Marec, Electrophysiologic characteristics of cells spanning the left ventricular wall of human heart: evidence for presence of M cells, Journal of the American College of Cardiology, 26 (1995) 185-192.

[113] F. Poveda, D. Gil, E. Marti, A. Andaluz, M. Ballester, F. Carreras, Helical Structure of the Cardiac Ventricular Anatomy Assessed by Diffusion Tensor Magnetic Resonance Imaging With Multiresolution Tractography, Revista espanola de cardiologia, 66 (2013) 782-790.

[114] S. Goktepe, O.J. Abilez, K.K. Parker, E. Kuhl, A multiscale model for eccentric and concentric cardiac growth through sarcomerogenesis, J Theor Biol, 265 (2010) 433-442.

[115] C.M. Otto, Valvular heart disease, W.B. Saunders, Philadelphia, 1999.

[116] C. Williams, K.P. Quinn, I. Georgakoudi, L.D. Black, 3rd, Young developmental age cardiac extracellular matrix promotes the expansion of neonatal cardiomyocytes in vitro, Acta biomaterialia, 10 (2014) 194-204.

[117] K.P. Anderson, R. Walker, P. Urie, P.R. Ershler, R.L. Lux, S.V. Karwandee, Myocardial Electrical Propagation in Patients with Idiopathic Dilated Cardiomyopathy, J Clin Invest, 92 (1993) 122-140.

[118] A.G. Kleber, M.J. Janse, F.J. Wilms-Schopmann, A.A. Wilde, R. Coronel, Changes in conduction velocity during acute ischemia in ventricular myocardium of the isolated porcine heart, Circulation, 73 (1986) 189-198.

[119] S. Rossi, S. Baruffi, A. Bertuzzi, M. Miragoli, D. Corradi, R. Maestri, R. Alinovi, A. Mutti, E. Musso, A. Sgoifo, D. Brisinda, R. Fenici, E. Macchi, Ventricular activation is impaired in aged rat hearts, Am J Physiol-Heart C, 295 (2008) H2336-H2347.

[120] V.G. Fast, A.G. Kleber, Anisotropic conduction in monolayers of neonatal rat heart cells cultured on collagen substrate, Circ Res, 75 (1994) 591-595.

[121] N. Bursac, K.K. Parker, S. Iravanian, L. Tung, Cardiomyocyte cultures with controlled macroscopic anisotropy: a model for functional electrophysiological studies of cardiac muscle, Circ Res, 91 (2002) e45-54.

[122] B. Liau, N. Christoforou, K.W. Leong, N. Bursac, Pluripotent stem cell-derived cardiac tissue patch with advanced structure and function, Biomaterials, 32 (2011) 9180-9187.

[123] D. Zhang, I.Y. Shadrin, J. Lam, H.Q. Xian, H.R. Snodgrass, N. Bursac, Tissue-engineered cardiac patch for advanced functional maturation of human ESC-derived cardiomyocytes, Biomaterials, 34 (2013) 5813-5820. 
[124] J.F. Wenk, D. Klepach, L.C. Lee, Z. Zhang, L. Ge, E.E. Tseng, A. Martin, S. Kozerke, J.H. Gorman, 3rd, R.C. Gorman, J.M. Guccione, First evidence of depressed contractility in the border zone of a human myocardial infarction, The Annals of thoracic surgery, 93 (2012) 1188-1193.

[125] G. Kissling, T. Gassenmaier, M.F. Wendt-Gallitelli, R. Jacob, Pressure-volume relations, elastic modulus, and contractile behaviour of the hypertrophied left ventricle of rats with Goldblatt II hypertension, Pflugers Archiv : European journal of physiology, 369 (1977) 213-221.

[126] H. Gosselin, X. Qi, J.L. Rouleau, Correlation between cardiac remodelling, function, and myocardial contractility in rat hearts 5 weeks after myocardial infarction, Can J Physiol Pharm, 76 (1998) 53-62.

[127] G. Hasenfuss, L.A. Mulieri, E.M. Blanchard, C. Holubarsch, B.J. Leavitt, F. Ittleman, N.R. Alpert, Energetics of isometric force development in control and volume-overload human myocardium.

Comparison with animal species, Circ Res, 68 (1991) 836-846.

[128] A. Agarwal, J.A. Goss, A. Cho, M.L. McCain, K.K. Parker, Microfluidic heart on a chip for higher throughput pharmacological studies, Lab Chip, 13 (2013) 3599-3608.

[129] S. Nishimura, S. Yasuda, M. Katoh, K.P. Yamada, H. Yamashita, Y. Saeki, K. Sunagawa, R. Nagai, T. Hisada, S. Sugiura, Single cell mechanics of rat cardiomyocytes under isometric, unloaded, and physiologically loaded conditions, American journal of physiology. Heart and circulatory physiology, 287 (2004) H196-202.

[130] P.A. Wassenaar, C.N. Eleswarpu, S.A. Schroeder, X. Mo, B.D. Raterman, R.D. White, A.

Kolipaka, Measuring age-dependent myocardial stiffness across the cardiac cycle using MR elastography: A reproducibility study, Magnetic resonance in medicine, (2015).

[131] I. Mirsky, T. Tajimi, K.L. Peterson, The Development of the Entire End-Systolic Pressure-Volume and Ejection Fraction Afterload Relations - a New Concept of Systolic Myocardial Stiffness, Circulation, 76 (1987) 343-356.

[132] N.R. Clark, N. Reichek, P. Bergey, E.A. Hoffman, D. Brownson, L. Palmon, L. Axel, Circumferential myocardial shortening in the normal human left ventricle. Assessment by magnetic resonance imaging using spatial modulation of magnetization, Circulation, 84 (1991) 67-74.

[133] C.C. Moore, C.H. Lugo-Olivieri, E.R. McVeigh, E.A. Zerhouni, Three-dimensional systolic strain patterns in the normal human left ventricle: characterization with tagged MR imaging, Radiology, 214 (2000) 453-466.

[134] N.B. Ingels, Jr., G.T. Daughters, 2nd, E.B. Stinson, E.L. Alderman, Measurement of midwall myocardial dynamics in intact man by radiography of surgically implanted markers, Circulation, 52 (1975) 859-867.

[135] D.H. Kim, E.A. Lipke, P. Kim, R. Cheong, S. Thompson, M. Delannoy, K.Y. Suh, L. Tung, A. Levchenko, Nanoscale cues regulate the structure and function of macroscopic cardiac tissue constructs, Proceedings of the National Academy of Sciences of the United States of America, 107 (2010) 565-570. [136] F. Qu, C.M. Ripplinger, V.P. Nikolski, C. Grimm, I.R. Efimov, Three-dimensional panoramic imaging of cardiac arrhythmias in rabbit heart, Journal of biomedical optics, 12 (2007) 044019.

[137] W.K. Weiwad, W.A. Linke, M.H. Wussling, Sarcomere length-tension relationship of rat cardiac myocytes at lengths greater than optimum, J Mol Cell Cardiol, 32 (2000) 247-259.

[138] P. Tracqui, J. Ohayon, An integrated formulation of anisotropic force-calcium relations driving spatio-temporal contractions of cardiac myocytes, Philos T R Soc A, 367 (2009) 4887-4905.

[139] E. Aikawa, P. Whittaker, M. Farber, K. Mendelson, R.F. Padera, M. Aikawa, F.J. Schoen, Human semilunar cardiac valve remodeling by activated cells from fetus to adult: implications for postnatal adaptation, pathology, and tissue engineering, Circulation, 113 (2006) 1344-1352.

[140] N.M. Rajamannan, F.J. Evans, E. Aikawa, K.J. Grande-Allen, L.L. Demer, D.D. Heistad, C.A. Simmons, K.S. Masters, P. Mathieu, K.D. O'Brien, F.J. Schoen, D.A. Towler, A.P. Yoganathan, C.M. Otto, Calcific Aortic Valve Disease: Not Simply a Degenerative Process A Review and Agenda for Research From the National Heart and Lung and Blood Institute Aortic Stenosis Working Group, Circulation, 124 (2011) 1783-1791. 
[141] M.R. Dweck, N.A. Boon, D.E. Newby, Calcific aortic stenosis: a disease of the valve and the myocardium, Journal of the American College of Cardiology, 60 (2012) 1854-1863.

[142] M.S. Sacks, A.P. Yoganathan, Heart valve function: a biomechanical perspective, Philos T R Soc B, 362 (2007) 1369-1391.

[143] I. Vesely, Heart valve tissue engineering, Circ Res, 97 (2005) 743-755.

[144] G. Marom, M. Peleg, R. Halevi, M. Rosenfeld, E. Raanani, A. Hamdan, R. Haj-Ali, Fluid-structure interaction model of aortic valve with porcine-specific collagen fiber alignment in the cusps, Journal of biomechanical engineering, 135 (2013) 101001-101006.

[145] R.B. Hinton, Jr., J. Lincoln, G.H. Deutsch, H. Osinska, P.B. Manning, D.W. Benson, K.E. Yutzey, Extracellular matrix remodeling and organization in developing and diseased aortic valves, Circ Res, 98 (2006) 1431-1438.

[146] J.T. Butcher, G.J. Mahler, L.A. Hockaday, Aortic valve disease and treatment: the need for naturally engineered solutions, Advanced drug delivery reviews, 63 (2011) 242-268.

[147] D.M. Brinkley, E.V. Gelfand, Valvular heart disease: classic teaching and emerging paradigms, The American journal of medicine, 126 (2013) 1035-1042.

[148] J.D. Hutcheson, E. Aikawa, W.D. Merryman, Potential drug targets for calcific aortic valve disease, Nature reviews. Cardiology, 11 (2014) 218-231.

[149] A.C. Liu, V.R. Joag, A.I. Gotlieb, The emerging role of valve interstitial cell phenotypes in regulating heart valve pathobiology, The American journal of pathology, 171 (2007) 1407-1418.

[150] C.Y.Y. Yip, C.A. Simmons, The aortic valve microenvironment and its role in calcific aortic valve disease, Cardiovascular Pathology, 20 (2011) 177-182.

[151] M.B. Chen, S. Srigunapalan, A.R. Wheeler, C.A. Simmons, A 3D microfluidic platform incorporating methacrylated gelatin hydrogels to study physiological cardiovascular cell-cell interactions, Lab Chip, 13 (2013) 2591-2598.

[152] J. Wylie-Sears, E. Aikawa, R.A. Levine, J.H. Yang, J. Bischoff, Mitral Valve Endothelial Cells With Osteogenic Differentiation Potential, Arterioscl Throm Vas, 31 (2011) 598-U266.

[153] N. Werner, S. Kosiol, T. Schiegl, P. Ahlers, K. Walenta, A. Link, M. Bohm, G. Nickenig, Circulating endothelial progenitor cells and cardiovascular outcomes, New Engl J Med, 353 (2005) 9991007.

[154] H.Y. Huang, S. Huang, Real-time strain mapping via biaxial stretching in heart valve tissues, Conference proceedings : ... Annual International Conference of the IEEE Engineering in Medicine and Biology Society. IEEE Engineering in Medicine and Biology Society. Annual Conference, 2012 (2012) 6653-6656.

[155] F.J. Schoen, Mechanisms of function and disease of natural and replacement heart valves, Annual review of pathology, 7 (2012) 161-183.

[156] C.M. Otto, Evaluation and management of chronic mitral regurgitation., New Engl J Med, 345 (2001) 740-746.

[157] L. Thomas, E. Foster, N.B. Schiller, Peak mitral inflow velocity predicts mitral regurgitation severity, Journal of the American College of Cardiology, 31 (1998) 174-179.

[158] P.M. Dohmen, A. Lembcke, H. Hotz, D. Kivelitz, W.F. Konertz, Ross operation with a tissueengineered heart valve, The Annals of thoracic surgery, 74 (2002) 1438-1442.

[159] H. Baumgartner, J. Hung, J. Bermejo, J.B. Chambers, A. Evangelista, B.P. Griffin, B. Iung, C.M. Otto, P.A. Pellikka, M. Quinones, Eae/Ase, Echocardiographic assessment of valve stenosis: EAE/ASE recommendations for clinical practice, European journal of echocardiography : the journal of the Working Group on Echocardiography of the European Society of Cardiology, 10 (2009) 1-25.

[160] M.S. Sacks, Y. Enomoto, J.R. Graybill, W.D. Merryman, A. Zeeshan, A.P. Yoganathan, R.J. Levy, R.C. Gorman, J.H. Gorman, 3rd, In-vivo dynamic deformation of the mitral valve anterior leaflet, The Annals of thoracic surgery, 82 (2006) 1369-1377.

[161] M.S. Sacks, W. David Merryman, D.E. Schmidt, On the biomechanics of heart valve function, Journal of biomechanics, 42 (2009) 1804-1824. 
[162] C.H. Yap, N. Saikrishnan, A.P. Yoganathan, Experimental measurement of dynamic fluid shear stress on the ventricular surface of the aortic valve leaflet, Biomech Model Mechanobiol, 11 (2012) 231 244.

[163] K. Schenke-Layland, I. Riemann, F. Opitz, K. Konig, K.J. Halbhuber, U.A. Stock, Comparative study of cellular and extracellular matrix composition of native and tissue engineered heart valves, Matrix biology : journal of the International Society for Matrix Biology, 23 (2004) 113-125.

[164] J.J. Song, H.C. Ott, Organ engineering based on decellularized matrix scaffolds, Trends in molecular medicine, 17 (2011) 424-432.

[165] C. Del Gaudio, A. Bianco, M. Grigioni, Electrospun bioresorbable trileaflet heart valve prosthesis for tissue engineering: in vitro functional assessment of a pulmonary cardiac valve design, Annali dell'Istituto superiore di sanita, 44 (2008) 178-186.

[166] S.F. Badylak, D. Taylor, K. Uygun, Whole-Organ Tissue Engineering: Decellularization and Recellularization of Three-Dimensional Matrix Scaffolds, Annu Rev Biomed Eng, 13 (2011) 27-53.

[167] P.M. Crapo, T.W. Gilbert, S.F. Badylak, An overview of tissue and whole organ decellularization processes, Biomaterials, 32 (2011) 3233-3243.

[168] R.H. Fu, Y.C. Wang, S.P. Liu, T.R. Shih, H.L. Lin, Y.M. Chen, J.H. Sung, C.H. Lu, J.R. Wei, Z.W. Wang, S.J. Huang, C.H. Tsai, W.C. Shyu, S.Z. Lin, Decellularization and Recellularization Technologies in Tissue Engineering, Cell transplantation, 23 (2014) 621-630.

[169] J.E. Nichols, J. Niles, M. Riddle, G. Vargas, T. Schilagard, L. Ma, K. Edward, S. La Francesca, J. Sakamoto, S. Vega, M. Ogadegbe, R. Mlcak, D. Deyo, L. Woodson, C. McQuitty, S. Lick, D. Beckles, E. Melo, J. Cortiella, Production and Assessment of Decellularized Pig and Human Lung Scaffolds, Tissue Eng Pt A, 19 (2013) 2045-2062.

[170] J.J. Song, J.P. Guyette, S.E. Gilpin, G. Gonzalez, J.P. Vacanti, H.C. Ott, Regeneration and experimental orthotopic transplantation of a bioengineered kidney, Nature medicine, 19 (2013) 646-651. [171] P. Akhyari, H. Aubin, P. Gwanmesia, M. Barth, S. Hoffmann, J. Huelsmann, K. Preuss, A.

Lichtenberg, The Quest for an Optimized Protocol for Whole-Heart Decellularization: A Comparison of Three Popular and a Novel Decellularization Technique and Their Diverse Effects on Crucial Extracellular Matrix Qualities, Tissue Eng Part C-Me, 17 (2011) 915-926.

[172] W.L. Grayson, M. Frohlich, K. Yeager, S. Bhumiratana, M.E. Chan, C. Cannizzaro, L.Q. Wan, X.S. Liu, X.E. Guo, G. Vunjak-Novakovic, Engineering anatomically shaped human bone grafts, Proceedings of the National Academy of Sciences of the United States of America, 107 (2010) 32993304.

[173] M. Bertanha, A. Moroz, R. Almeida, F.C. Alves, M.J.A. Valerio, R. Moura, M.A.C. Domingues, M.L. Sobreira, E. Deffune, Tissue-engineered blood vessel substitute by reconstruction of endothelium using mesenchymal stem cells induced by platelet growth factors, J Vasc Surg, 59 (2014) 1677-1685. [174] J.P. Guyette, S.E. Gilpin, J.M. Charest, L.F. Tapias, X. Ren, H.C. Ott, Perfusion decellularization of whole organs, Nat Protoc, 9 (2014) 1451-1468.

[175] H.C. Ott, T.S. Matthiesen, S.K. Goh, L.D. Black, S.M. Kren, T.I. Netoff, D.A. Taylor, Perfusiondecellularized matrix: using nature's platform to engineer a bioartificial heart, Nature medicine, 14 (2008) 213-221.

[176] T.Y. Lu, B. Lin, J. Kim, M. Sullivan, K. Tobita, G. Salama, L. Yang, Repopulation of decellularized mouse heart with human induced pluripotent stem cell-derived cardiovascular progenitor cells, Nat Commun, 4 (2013).

[177] S.F. Badylak, Decellularized Allogeneic and Xenogeneic Tissue as a Bioscaffold for Regenerative Medicine: Factors that Influence the Host Response, Annals of biomedical engineering, 42 (2014) 1517 1527.

[178] T.J. Keane, R. Londono, N.J. Turner, S.F. Badylak, Consequences of ineffective decellularization of biologic scaffolds on the host response, Biomaterials, 33 (2012) 1771-1781.

[179] D.I. Braghirolli, D. Steffens, P. Pranke, Electrospinning for regenerative medicine: a review of the main topics, Drug discovery today, 19 (2014) 743-753. 
[180] J.H. He, H.Y. Kong, R.R. Yang, H. Dou, N. Faraz, L. Wang, C. Feng, Review on Fiber Morphology Obtained by Bubble Electrospinning and Blown Bubble Spinning, Therm Sci, 16 (2012) 1263-1279.

[181] Y. Srivastava, M. Marquez, T. Thorsen, Microfluidic electrospinning of biphasic nanofibers with Janus morphology, Biomicrofluidics, 3 (2009).

[182] W. Nuansing, D. Frauchiger, F. Huth, A. Rebollo, R. Hillenbrand, A.M. Bittner, Electrospinning of peptide and protein fibres: approaching the molecular scale, Faraday Discuss, 166 (2013) 209-221.

[183] L.H. Meng, O. Arnoult, M. Smith, G.E. Wnek, Electrospinning of in situ crosslinked collagen nanofibers, J Mater Chem, 22 (2012) 19412-19417.

[184] W. Fu, Z.L. Liu, B. Feng, R.J. Hu, X.M. He, H. Wang, M. Yin, H.M. Huang, H.B. Zhang, W. Wang, Electrospun gelatin/PCL and collagen/PLCL scaffolds for vascular tissue engineering, Int J Nanomed, 9 (2014) 2335-2344.

[185] S.A. Sell, M.J. McClure, K. Garg, P.S. Wolfe, G.L. Bowlin, Electrospinning of collagen/biopolymers for regenerative medicine and cardiovascular tissue engineering, Advanced drug delivery reviews, 61 (2009) 1007-1019.

[186] R. Vasita, D.S. Katti, Nanofibers and their applications in tissue engineering, Int J Nanomed, 1 (2006) 15-30.

[187] S.V. Fridrikh, J.H. Yu, M.P. Brenner, G.C. Rutledge, Controlling the fiber diameter during electrospinning, Phys Rev Lett, 90 (2003).

[188] J. Nam, Y. Huang, S. Agarwal, J. Lannutti, Improved cellular infiltration in electrospun fiber via engineered porosity, Tissue engineering, 13 (2007) 2249-2257.

[189] M.I. Van Lieshout, C.M. Vaz, M.C.M. Rutten, G.W.M. Peters, F.P.T. Baaijens, Electrospinning versus knitting: two scaffolds for tissue engineering of the aortic valve, J Biomat Sci-Polym E, 17 (2006) 77-89.

[190] V. Beachley, X.J. Wen, Effect of electrospinning parameters on the nanofiber diameter and length, Mat Sci Eng C-Bio S, 29 (2009) 663-668.

[191] W.G. Cui, Y. Zhou, J. Chang, Electrospun nanofibrous materials for tissue engineering and drug delivery, Sci Technol Adv Mat, 11 (2010).

[192] W. Ji, Y. Sun, F. Yang, J.J.J.P. van den Beucken, M.W. Fan, Z. Chen, J.A. Jansen, Bioactive Electrospun Scaffolds Delivering Growth Factors and Genes for Tissue Engineering Applications, Pharm Res-Dordr, 28 (2011) 1259-1272.

[193] D. Kai, M.P. Prabhakaran, G.R. Jin, S. Ramakrishna, Biocompatibility evaluation of electrically conductive nanofibrous scaffolds for cardiac tissue engineering, J Mater Chem B, 1 (2013) 2305-2314. [194] Y. Li, J.J. Fu, R.S. Chen, M. Huang, B. Gao, K.F. Huo, L. Wang, P.K. Chu, Core-shell TiC/C nanofiber arrays decorated with copper nanoparticles for high performance non-enzymatic glucose sensing, Sensor Actuat B-Chem, 192 (2014) 474-479.

[195] H.J. Lee, H.S. Kim, H.O. Kim, W.G. Koh, Micropatterns of double-layered nanofiber scaffolds with dual functions of cell patterning and metabolite detection, Lab Chip, 11 (2011) 2849-2857. [196] C.J. Luo, S.D. Stoyanov, E. Stride, E. Pelan, M. Edirisinghe, Electrospinning versus fibre production methods: from specifics to technological convergence, Chem Soc Rev, 41 (2012) 4708-4735. [197] G.G. Chase, J.S. Varabhas, D.H. Reneker, New Methods to Electrospin Nanofibers, J Eng Fiber Fabr, 6 (2011) 32-38.

[198] D.I. Zeugolis, S.T. Khew, E.S.Y. Yew, A.K. Ekaputra, Y.W. Tong, L.Y.L. Yung, D.W. Hutmacher, C. Sheppard, M. Raghunath, Electro-spinning of pure collagen nano-fibres - Just an expensive way to make gelatin?, Biomaterials, 29 (2008) 2293-2305.

[199] D.W. Hutmacher, P.D. Dalton, Melt Electrospinning, Chem-Asian J, 6 (2011) 44-56.

[200] P. Mellado, H.A. McIlwee, M.R. Badrossamay, J.A. Goss, L. Mahadevan, K.K. Parker, A simple model for nanofiber formation by rotary jet-spinning, Appl Phys Lett, 99 (2011).

[201] L. Deravi, Golecki HM, Parker, KK, Protein-based textiles: bio-inspired and bio-derived materials for medical and non-medical applications Journal of Chemical and Biological Interfaces, 1 (2013) 25-34. 
[202] K. Sarkar, C. Gomez, S. Zambrano, M. Ramirez, E. de Hoyos, H. Vasquez, K. Lozano, Electrospinning to Forcespinning (TM), Mater Today, 13 (2010) 12-14.

[203] B. Wang, M.E. Tedder, C.E. Perez, G. Wang, A.L. de Jongh Curry, F. To, S.H. Elder, L.N. Williams, D.T. Simionescu, J. Liao, Structural and biomechanical characterizations of porcine myocardial extracellular matrix, Journal of materials science. Materials in medicine, 23 (2012) 1835-1847.

[204] B. Wang, A. Borazjani, M. Tahai, A.L. Curry, D.T. Simionescu, J. Guan, F. To, S.H. Elder, J. Liao, Fabrication of cardiac patch with decellularized porcine myocardial scaffold and bone marrow mononuclear cells, Journal of biomedical materials research. Part A, 94 (2010) 1100-1110. [205] J. Luo, S.A. Korossis, S.P. Wilshaw, L.M. Jennings, J. Fisher, E. Ingham, Development and characterization of acellular porcine pulmonary valve scaffolds for tissue engineering, Tissue engineering. Part A, 20 (2014) 2963-2974.

[206] Q. Lu, K. Ganesan, D.T. Simionescu, N.R. Vyavahare, Novel porous aortic elastin and collagen scaffolds for tissue engineering, Biomaterials, 25 (2004) 5227-5237.

[207] H.C. Ott, T.S. Matthiesen, S.K. Goh, L.D. Black, S.M. Kren, T.I. Netoff, D.A. Taylor, Perfusiondecellularized matrix: using nature's platform to engineer a bioartificial heart, Nature medicine, 14 (2008) 213-221.

[208] M. Shevach, S. Fleischer, A. Shapira, T. Dvir, Gold Nanoparticle-Decellularized Matrix Hybrids for Cardiac Tissue Engineering, Nano letters, 14 (2014) 5792-5796.

[209] S. Rajabi-Zeleti, S. Jalili-Firoozinezhad, M. Azarnia, F. Khayyatan, S. Vandat, S. Nikeghbalian, A. Khademhosseini, H. Baharvand, N. Aghdami, The behavior of cardiac progenitor cells on macroporous pericardium-derived scaffolds, Biomaterials, 35 (2014) 970-982.

[210] P.L. Sanchez, M.E. Fernandez-Santos, S. Costanza, A.M. Climent, I. Moscoso, M.A. GonzalezNicolas, R. Sanz-Ruiz, H. Rodriguez, S.M. Kren, G. Garrido, J.L. Escalante, J. Bermejo, J. Elizaga, J. Menarguez, R. Yotti, C.P. del Villar, M.A. Espinosa, M.S. Guillem, J.T. Willerson, A. Bernad, R. Matesanz, D.A. Taylor, F. Fernandez-Aviles, Acellular human heart matrix: A critical step toward whole heart grafts, Biomaterials, 61 (2015) 279-289.

[211] J. Yu, A.R. Lee, W.H. Lin, C.W. Lin, Y.K. Wu, W.B. Tsai, Electrospun PLGA fibers incorporated with functionalized biomolecules for cardiac tissue engineering, Tissue engineering. Part A, 20 (2014) 1896-1907.

[212] H.G. Senel Ayaz, A. Perets, H. Ayaz, K.D. Gilroy, M. Govindaraj, D. Brookstein, P.I. Lelkes, Textile-templated electrospun anisotropic scaffolds for regenerative cardiac tissue engineering, Biomaterials, 35 (2014) 8540-8552.

[213] S. Fleischer, R. Feiner, A. Shapira, J. Ji, X. Sui, H. Daniel Wagner, T. Dvir, Spring-like fibers for cardiac tissue engineering, Biomaterials, 34 (2013) 8599-8606.

[214] R. Rai, M. Tallawi, C. Frati, A. Falco, A. Gervasi, F. Quaini, J.A. Roether, T. Hochburger, D.W. Schubert, L. Seik, N. Barbani, L. Lazzeri, E. Rosellini, A.R. Boccaccini, Bioactive Electrospun Fibers of Poly(glycerol sebacate) and Poly(epsilon-caprolactone) for Cardiac Patch Application, Advanced healthcare materials, (2015).

[215] N. Masoumi, B.L. Larson, N. Annabi, M. Kharaziha, B. Zamanian, K.S. Shapero, A.T. Cubberley, G. Camci-Unal, K.B. Manning, J.E. Mayer, Jr., A. Khademhosseini, Electrospun PGS:PCL microfibers align human valvular interstitial cells and provide tunable scaffold anisotropy, Advanced healthcare materials, 3 (2014) 929-939.

[216] C.M. Hobson, N.J. Amoroso, R. Amini, E. Ungchusri, Y. Hong, A. D'Amore, M.S. Sacks, W.R. Wagner, Fabrication of elastomeric scaffolds with curvilinear fibrous structures for heart valve leaflet engineering, Journal of biomedical materials research. Part A, 103 (2015) 3101-3106.

[217] S. Hinderer, J. Seifert, M. Votteler, N. Shen, J. Rheinlaender, T.E. Schaffer, K. Schenke-Layland, Engineering of a bio-functionalized hybrid off-the-shelf heart valve, Biomaterials, 35 (2014) 2130-2139.

[218] D.M. Zhang, J. Chang, Electrospinning of Three-Dimensional Nanofibrous Tubes with Controllable Architectures, Nano letters, 8 (2008) 3283-3287.

[219] G. Argento, M. Simonet, C.W. Oomens, F.P. Baaijens, Multi-scale mechanical characterization of scaffolds for heart valve tissue engineering, Journal of biomechanics, 45 (2012) 2893-2898. 
[220] T.R. Jones, A.E. Carpenter, M.R. Lamprecht, J. Moffat, S.J. Silver, J.K. Grenier, A.B. Castoreno, U.S. Eggert, D.E. Root, P. Golland, D.M. Sabatini, Scoring diverse cellular morphologies in image-based screens with iterative feedback and machine learning, Proceedings of the National Academy of Sciences of the United States of America, 106 (2009) 1826-1831.

[221] F. Klingberg, B. Hinz, E.S. White, The myofibroblast matrix: implications for tissue repair and fibrosis, The Journal of pathology, 229 (2013) 298-309.

[222] S.W. van den Borne, J. Diez, W.M. Blankesteijn, J. Verjans, L. Hofstra, J. Narula, Myocardial remodeling after infarction: the role of myofibroblasts, Nature reviews. Cardiology, 7 (2010) 30-37.

[223] S. Rohr, Myofibroblasts in diseased hearts: new players in cardiac arrhythmias?, Heart rhythm : the official journal of the Heart Rhythm Society, 6 (2009) 848-856.

[224] V. Serpooshan, M. Zhao, S.A. Metzler, K. Wei, P.B. Shah, A. Wang, M. Mahmoudi, A.V.

Malkovskiy, J. Rajadas, M.J. Butte, D. Bernstein, P. Ruiz-Lozano, The effect of bioengineered acellular collagen patch on cardiac remodeling and ventricular function post myocardial infarction, Biomaterials, 34 (2013) 9048-9055.

[225] T. Dvir, B.P. Timko, M.D. Brigham, S.R. Naik, S.S. Karajanagi, O. Levy, H. Jin, K.K. Parker, R. Langer, D.S. Kohane, Nanowired three-dimensional cardiac patches, Nat Nanotechnol, 6 (2011) 720-725. [226] M. Kharaziha, S.R. Shin, M. Nikkhah, S.N. Topkaya, N. Masoumi, N. Annabi, M.R. Dokmeci, A.

Khademhosseini, Tough and flexible CNT-polymeric hybrid scaffolds for engineering cardiac constructs, Biomaterials, 35 (2014) 7346-7354.

[227] C.L. Hastings, E.T. Roche, E. Ruiz-Hernandez, K. Schenke-Layland, C.J. Walsh, G.P. Duffy, Drug and cell delivery for cardiac regeneration, Advanced drug delivery reviews, 84 (2015) 85-106.

[228] X. Hu, S. Liu, G. Zhou, Y. Huang, Z. Xie, X. Jing, Electrospinning of polymeric nanofibers for drug delivery applications, Journal of controlled release : official journal of the Controlled Release Society, 185 (2014) 12-21.

[229] L. Weng, J. Xie, Smart electrospun nanofibers for controlled drug release: recent advances and new perspectives, Current pharmaceutical design, 21 (2015) 1944-1959.

[230] F.R. Formiga, B. Pelacho, E. Garbayo, I. Imbuluzqueta, P. Diaz-Herraez, G. Abizanda, J.J. Gavira, T. Simon-Yarza, E. Albiasu, E. Tamayo, F. Prosper, M.J. Blanco-Prieto, Controlled delivery of fibroblast growth factor-1 and neuregulin-1 from biodegradable microparticles promotes cardiac repair in a rat myocardial infarction model through activation of endogenous regeneration, Journal of controlled release : official journal of the Controlled Release Society, 173 (2014) 132-139.

[231] W.C. Chen, B.G. Lee, D.W. Park, K. Kim, H. Chu, K. Kim, J. Huard, Y. Wang, Controlled dual delivery of fibroblast growth factor- 2 and Interleukin-10 by heparin-based coacervate synergistically enhances ischemic heart repair, Biomaterials, 72 (2015) 138-151.

[232] S. Browne, A. Pandit, Biomaterial-mediated modification of the local inflammatory environment, Frontiers in bioengineering and biotechnology, 3 (2015) 67.

[233] N. Bursac, Y. Loo, K. Leong, L. Tung, Novel anisotropic engineered cardiac tissues: studies of electrical propagation, Biochemical and biophysical research communications, 361 (2007) 847-853.

[234] X.H. Zong, H. Bien, C.Y. Chung, L.H. Yin, D.F. Fang, B.S. Hsiao, B. Chu, E. Entcheva, Electrospun fine-textured scaffolds for heart tissue constructs, Biomaterials, 26 (2005) 5330-5338.

[235] H. Kenar, G.T. Kose, M. Toner, D.L. Kaplan, V. Hasirci, A 3D aligned microfibrous myocardial tissue construct cultured under transient perfusion, Biomaterials, 32 (2011) 5320-5329.

[236] D. Kai, Q.L. Wang, H.J. Wang, M.P. Prabhakaran, Y. Zhang, Y.Z. Tan, S. Ramakrishna, Stem cellloaded nanofibrous patch promotes the regeneration of infarcted myocardium with functional improvement in rat model, Acta biomaterialia, 10 (2014) 2727-2738.

[237] A.G. Guex, A. Frobert, J. Valentin, G. Fortunato, D. Hegemann, S. Cook, T.P. Carrel, H.T. Tevaearai, M.N. Giraud, Plasma-functionalized electrospun matrix for biograft development and cardiac function stabilization, Acta biomaterialia, 10 (2014) 2996-3006.

[238] Q.Z. Chen, A. Bismarck, U. Hansen, S. Junaid, M.Q. Tran, S.E. Harding, N.N. Ali, A.R. Boccaccini, Characterisation of a soft elastomer poly(glycerol sebacate) designed to match the mechanical properties of myocardial tissue, Biomaterials, 29 (2008) 47-57. 
[239] K. Kang, L. Sun, Y. Xiao, S.H. Li, J. Wu, J. Guo, S.L. Jiang, L. Yang, T.M. Yau, R.D. Weisel, M. Radisic, R.K. Li, Aged human cells rejuvenated by cytokine enhancement of biomaterials for surgical ventricular restoration, Journal of the American College of Cardiology, 60 (2012) 2237-2249.

[240] B. Weber, J. Robert, A. Ksiazek, Y. Wyss, L. Frese, J. Slamecka, D. Kehl, P. Modregger, S. Peter, M. Stampanoni, S. Proulx, V. Falk, S.P. Hoerstrup, Living-engineered valves for transcatheter venous valve repair, Tissue engineering. Part C, Methods, 20 (2014) 451-463.

[241] S. Ghazanfari, A. Driessen-Mol, B. Sanders, P.E. Dijkman, S.P. Hoerstrup, F.P. Baaijens, C.V. Bouten, In Vivo Collagen Remodeling in the Vascular Wall of Decellularized Stented Tissue-Engineered Heart Valves, Tissue engineering. Part A, 21 (2015) 2206-2215.

[242] B. Weber, J. Scherman, M.Y. Emmert, J. Gruenenfelder, R. Verbeek, M. Bracher, M. Black, J. Kortsmit, T. Franz, R. Schoenauer, L. Baumgartner, C. Brokopp, I. Agarkova, P. Wolint, G. Zund, V. Falk, P. Zilla, S.P. Hoerstrup, Injectable living marrow stromal cell-based autologous tissue engineered heart valves: first experiences with a one-step intervention in primates, Eur Heart J, 32 (2011) 2830-2840. [243] R. Langer, J.P. Vacanti, Tissue engineering, Science, 260 (1993) 920-926.

[244] M. Lovett, K. Lee, A. Edwards, D.L. Kaplan, Vascularization Strategies for Tissue Engineering, Tissue Eng Part B-Re, 15 (2009) 353-370.

[245] E.C. Novosel, C. Kleinhans, P.J. Kluger, Vascularization is the key challenge in tissue engineering, Advanced drug delivery reviews, 63 (2011) 300-311.

[246] S. Baiguera, D. Ribatti, Endothelialization approaches for viable engineered tissues, Angiogenesis, 16 (2013) 1-14.

[247] J.L. Drury, D.J. Mooney, Hydrogels for tissue engineering: scaffold design variables and applications, Biomaterials, 24 (2003) 4337-4351.

[248] P.O. Rujitanaroj, R. Aid-Launais, S.Y. Chew, C. Le Visage, Polysaccharide electrospun fibers with sulfated poly(fucose) promote endothelial cell migration and VEGF-mediated angiogenesis, Biomater Sci-Uk, 2 (2014) 843-852.

[249] Y. Miyagi, L.L. Chiu, M. Cimini, R.D. Weisel, M. Radisic, R.K. Li, Biodegradable collagen patch with covalently immobilized VEGF for myocardial repair, Biomaterials, 32 (2011) 1280-1290.

[250] L.L. Chiu, M. Radisic, Scaffolds with covalently immobilized VEGF and Angiopoietin-1 for vascularization of engineered tissues, Biomaterials, 31 (2010) 226-241.

[251] M. Dobaczewski, Y. Xia, M. Bujak, C. Gonzalez-Quesada, N.G. Frangogiannis, CCR5 Signaling Suppresses Inflammation and Reduces Adverse Remodeling of the Infarcted Heart, Mediating Recruitment of Regulatory T Cells, American Journal of Pathology, 176 (2010) 2177-2187.

[252] J.G. Merrell, S.W. McLaughlin, L. Tie, C.T. Laurencin, A.F. Chen, L.S. Nair, Curcumin-loaded poly(epsilon-caprolactone) nanofibres: diabetic wound dressing with anti-oxidant and anti-inflammatory properties, Clinical and experimental pharmacology \& physiology, 36 (2009) 1149-1156.

[253] E.R. Kenawy, F.I. Abdel-Hay, M.H. El-Newehy, G.E. Wnek, Controlled release of ketoprofen from electrospun poly(vinyl alcohol) nanofibers, Mat Sci Eng a-Struct, 459 (2007) 390-396.

[254] A. Nel, T. Xia, L. Madler, N. Li, Toxic potential of materials at the nanolevel, Science, 311 (2006) 622-627.

[255] W.A. Shewhart, W.E. Deming, Statistical method from the viewpoint of quality control, The Graduate school, the Department of agriculture, Washington,, 1939.

[256] C.M. Hinckley, Defining the best quality-control systems by design and inspection, Clinical chemistry, 43 (1997) 873-879. 